\title{
Paleothermal and seismic constraints on late Miocene- Pliocene uplift and deformation in the Torquay sub-basin, southern Australian margin
}

S. P. HOLFORD ${ }^{1 *}$, R. R. HILLIS ${ }^{1,2}$, I. R. DUDDY ${ }^{3}$, P. F. GREEN ${ }^{3}$, D. R. TASSONE ${ }^{1}$ AND M. S. STOKER ${ }^{4}$

${ }^{1}$ Australian School of Petroleum, Centre for Tectonics, Resources and Exploration (TRaX), University of Adelaide, SA 5005, Australia

${ }^{2}$ Now at: Deep Exploration Technologies Cooperative Research Centre, University of Adelaide, SA 5005, Australia

${ }^{3}$ Geotrack International Pty Ltd, 37 Melville Road, Brunswick West, Victoria 3055, Australia

${ }^{4}$ British Geological Survey, Murchison House, West Mains Road, Edinburgh EH9 3LA, UK

*Corresponding author (simon.holford@adelaide.edu.au)

The passive southern margin of the Australian continent contains a rich record of late Miocene-Pliocene neotectonic deformation and uplift that continues to the present day as witnessed by unusually high levels of seismicity for a so-called 'stable continental region'. To date however, few studies have sought to estimate the magnitude of exhumation triggered by this deformation and uplift. Here we combine apatite fission track analysis (AFTA), apatite (U-Th)/He dating and vitrinite reflectance (VR) data from the Nerita-1 well in the Torquay sub-basin with seismic reflection data from this basin and the adjoining Otway Ranges to constrain the magnitude and driving mechanisms of exhumation in this part of the southern Australian margin. The Cenozoic succession in this basin has been deformed by folding and reverse faulting and contains a major, low-angle mid-Miocene unconformity that can be traced for distances of $\sim 1500 \mathrm{~km}$ along the margin. Paleothermal data from Nerita- 1 show that the sub-mid-Miocene succession has been more deeply buried by $\sim 1 \mathrm{~km}$ of now missing section, and indicate that exhumation began between 10 and $5 \mathrm{Ma}$, in excellent agreement with stratigraphic constraints. Our estimates of removed section and higher than previous estimates based on extrapolation of seismic reflectors, but are corroborated by AFTA results from nearby wells. Seismic data show that late Miocene-onwards intraplate 
deformation in the Torquay-sub-basin and Otway Ranges has been accomplished by reverse-reactivation of normal faults within Cretaceous-early Paleogene syn-rift successions, resulting in folding of overlying post-rift late Paleogene-Neogene sediments. The probable cause of this deformation and uplift is increased levels of intraplate stress induced by enhanced coupling of the Indo-Australian and Pacific plates $\sim 10 \mathrm{Myr}$ ago, and our results thus demonstrate the key role that plate boundary-controlled stress fields play in intraplate uplift and deformation.

KEY WORDS Australia, passive margins, uplift, exhumation, denudation, intraplate deformation, inversion, thermochronology, seismic reflection.

\section{INTRODUCTION}

There is growing recognition that many 'passive' continental margins around the world have experienced significant intraplate deformation and uplift subsequent to their formation (Doré et al. 2002; Holford et al. 2009a). The thick successions of syn- and post-rift sedimentary rocks that accumulate during and after continental breakup, combined with the constraints on crustal structure provided by seismic data acquired during hydrocarbon exploration ${ }_{2}$ make such margins superb natural laboratories for studying the driving forces and mechanics of intraplate deformation.

One such passive margin that has witnessed appreciable post-rift intraplate deformation is the southeastern Australian continental margin (Hill et al. 1995; Dickinson et al. 2002; Hillis et al. 2008a). The Australian continent (Figure 1) has a relatively high level of seismicity (seismic moment release rate $\sim 10^{-16}-10^{-17} \mathrm{~s}^{-1}$ ) compared to analogous continental interiors such as Europe and Africa (Leonard 2008; Sandiford \& Egholm 2008; Braun et al. 2009), and numerous neotectonic features (e.g. Miocene-Quaternary fault scarps) have been identified in recent years (Clark \& McCue 2003; Sandiford 2003; Quigley et al. 2006). The density of neotectonic structures and present-day seismic activity is particularly high in southeastern Australia, where several distinct modes of recent and ongoing intraplate deformation can be recognised (Sandiford et al. 2009). In the topographically elevated Flinders, Mt Lofty, southeastern Highlands and the Otway and Strzelecki Ranges, numerous Quaternary fault scarps have been identified (Sandiford 2003; Célérier et al. 2005; Quigley et al. 2006; Holdgate et al. 2008). Reverse motions can be demonstrated for many of these faults and paleoseismic studies have estimated Quaternary slip-rates as high as $20-150 \mathrm{mMa}^{-1}$ (Sandiford 2003; Quigley et al. 2006). 
At a larger scale, topographic undulations with amplitudes of order $\sim 100 \mathrm{~m}$ and wavelengths of $\sim 10^{2} \mathrm{~km}$ and best demonstrated by the juxtaposition of the Flinders Ranges with the anomalously low Frome and Torrens Basins, are indicative of lithospheric buckling (Célérier et al. 2005). In southwest Victoria, the remnants of early Pliocene strandlines that developed when sea levels were $\sim 65 \mathrm{~m}$ higher than present-day levels now occur at elevations of $\sim 180 \mathrm{~m} \mathrm{ASL}$, indicating $>100 \mathrm{~m}$ of post-early-mid Pliocene uplift (Sandiford et al. 2004; Wallace et al. 2005).

A further expression of this neotectonic activity is a widespread, low angle $\left(<1-5^{\circ}\right)$ tectonic unconformity close to the Miocene-Pliocene boundary that can be traced for $\sim 1500 \mathrm{~km}$ from the Gulf St Vincent and Murray Basins in the west to the Otway and Gippsland Basins in the east (Dickinson et al. 2002). Despite the significant recent advances in understanding the neotectonic record of southeastern Australia, there have been relatively few efforts to quantify the amount of exhumation resulting from this intraplate deformation (e.g. Cooper \& Hill 1997; Green et al. 2004), and in particular, the amount recorded by this unconformity. Here we present apatite fission track analysis (AFTA), apatite (U-Th)/He and vitrinite reflectance (VR) data from exploration wells in the Torquay-sub basin (TSB) of the eastern Otway Basin (Figure 2), where numerous Miocene-Quaternary reverse faults and folds have been identified and the Miocene-Pliocene unconformity is well developed (e.g. Dickinson et al. 2002). We also present seismic data that help constrain the mode of intraplate deformation in the Torquay sub-basin and the adjacent Otway Ranges. We conclude by discussing the driving forces responsible for this deformation and the implications of our findings for the ongoing debate regarding the timing and origin of uplift in the southeastern Highlands.

\section{GEOLOGY OF THE TORQUAY SUB-BASIN}

The TSB represents the mostly offshore extension of the eastern Otway Basin (Figure 2), which is one of a series of extensional sedimentary basins that formed during late Jurassic-Paleogene rifting along the southern Australian margin. Consequently, the Otway Basin shares many structural and stratigraphic affinities with the adjacent Bass and Gippsland basins (Figure 3; Norvick \& Smith 2001). The TSB contains a number of normal-fault controlled Cretaceous-Neogene depocentres (the 5-7 km thick Basin Deep and 2-5 km thick Snail Terrace; Trupp et al. 1994). It is bounded to the northwest and southeast by the Otway Ranges and Mornington Peninsula, respectively, two NE-SW-trending structural highs that witnessed compression, uplift and exhumation during both the mid-Cretaceous and late 
Cenozoic (Dickinson et al. 2002; Green et al. 2004). The TSB contains a series of late Cenozoic NE-SW-trending anticlines (Trupp et al. 1994). The stratigraphy of the basin is constrained by three exploration wells (Figure 2; Nerita-1, Snail-1 and Wild Dog-1), but many more wells have tested similar successions in the onshore eastern Otway Basin.

The basement to the TSB comprises Lower Paleozoic metasedimentary and volcanic rocks that are overlain by largely non-marine Upper Jurassic-Lower Cretaceous Otway Group, whose thicknesses demonstrate strong control by normal faults (Messent et al. 1999). All wells in the TSB bottom out in the Barremian-Albian Eumeralla Formation (Figure 3), a thick sequence of volcanogenic sandstones deposited in fluvial channels, and finer grained inter-channel sandstones, mudstones and shales (Duddy 2003). The volcanogenic clastic rocks were largely derived from contemporaneous dacitic volcanism (Duddy 2003). A major stratigraphic break at the top of the Eumeralla Formation records a regional uplift and exhumation episode, constrained by AFTA studies as beginning between 100 and 95 Ma that affected large areas of southern and eastern Australia (Duddy 1994, 2009; Hill et al. 1995). AFTA and VR data from onshore wells such as Anglesea-1 and Olangolah-1 indicate erosion of up to 2-3 km of additional Eumeralla Formation section from the Otway Ranges during this episode (Green et al. 1995, 2004; Cooper \& Hill 1997).

The non-marine Campanian-early Eocene Eastern View Group overlies the Otway Group (Figure 3), above an unconformity that represents a time gap of at least 20 Myr (Messent et al. 1999). The Eastern View Group is $683 \mathrm{~m}$ thick at Nerita-1 but much thinner at Snail-1 (38 m) and Wild Dog-1 (153 m). Lower parts of the Eastern View Group are equivalent to the Sherbrook Group in the Otway Basin, and upper parts are equivalent to the Wangerrip Group (Duddy 2003). Holdgate et al. (2001) noted sedimentological and stratigraphic affinities between early Eocene coal measures and underlying mudstones and sandstones in the Eastern View Group of the onshore TSB and similar facies in the Pember Mudstone and Pebble Point Formation in the adjacent Otway Basin. This suggests stratigraphic continuity between the TSB and Otway Basin, implying that during the early Paleogene the Otway Ranges were not yet a structural divide (Holdgate et al. 2001). The Eastern View Group is itself overlain by the terrestrial and paralic Demons Bluff Group (middle-late Eocene to early Oligocene) that witnesses an increasing marine influence on sedimentation (Messent et al. 1999). A regional mid-Eocene unconformity separates the Eastern View Group from the Demons Bluff Group 
(Holdgate et al. 2003). Both onshore and offshore, the unconformity is locally angular (up to $5^{\circ}$ ) and erosional (Trupp et al. 1994; Holdgate et al. 2003). The Demons Bluff Group (thickness varies between $\sim 285-420 \mathrm{~m}$ ) consists of the basal, transgressive, sandy Boonah Formation, the extensive, shallow marine Anglesea Siltstone and the uppermost Angahook Formation, a lithologically varied unit containing sand, clay, gravel, tuffs and basalt (Trupp et al. 1994).

The Demons Bluff Group is unconformably overlain by the late OligoceneMiocene Torquay Group (Figure 3), which largely comprises marine carbonates and has a maximum thickness of $~ 700 \mathrm{~m}$ in the Basin Deep (Messent et al. 1999). McLaren et al. (2009) present ${ }^{40} \mathrm{Ar} /{ }^{39} \mathrm{Ar}$ whole-rock ages which constrain the eruption age of Angahook Formation basalts to $28.7 \mathrm{Ma}$ (close to the European RupelianChattian boundary within the Oligocene) whilst strontium isotope ages of calcitic bioclasts in the overlying Torquay Group range between 27.9 and 24.2 Ma for the Jan Juc Marl and 24.24 Ma for the base of the age-equivalent Point Addis Limestone.

A widespread, low angle (generally $<1-5^{\circ}$ ) unconformity separates variably folded Torquay Group sediments from overlying Pliocene-Holocene sediments (Dickinson et al. 2002). It is observed in the Gulf St Vincent, Murray, Otway, Port Phillip and Gippsland basins (Dickinson et al. 2001, 2002) and is imaged by seismic data in the TSB (Figure 4). In all basins around southeast Australia, the underlying Miocene strata have been subjected to folding, faulting or erosion, and thus a change in eustatic sea level or climate cannot be invoked to explain its origin (Dickinson et al. 2002). The unconformity is most pronounced adjacent to the uplifted Otway and Strzelecki Ranges and becomes conformable in distal offshore locations (Dickinson et al. 2002). Its age is best constrained in the central Otway Basin (e.g. the Muddy Creek-Grange Burn area) and Port Phillip Basin (near Geelong) where foraminferal assemblages and strontium isotope ages from mollusc fauna indicate ages of $\sim 10$ Ma for late Miocene sediments underlying the unconformity and $\sim 5 \mathrm{Ma}$ for early Pliocene sediments that overlie it (Dickinson et al. 2002; McGowran et al. 2004).

There is abundant evidence for deformation of Miocene sediments by folding and reverse faulting around the TSB, broadly coeval with the timing of the unconformity (Dickinson et al. 2001, 2002). Based on extrapolation of reflectors on depth-converted seismic lines, Dickinson et al. (2002) estimated that a maximum of $\sim 400 \mathrm{~m}$ of Miocene section has been removed from the Torquay Group in the TSB (near Nerita-1). Although this thickness of missing section is not insignificant when considering that the preserved thickness of the Torquay Group at Nerita-1 is $~ 640 \mathrm{~m}$, 
it is markedly lower than the $\sim 750-950 \mathrm{~m}$ of late Miocene (12-7 Ma) exhumation at Anglesea-1 near the Otway Ranges, as estimated on the basis of AFTA, VR and apatite (U-Th)/He data (Green et al. 2004).

\section{THERMAL HISTORY RECONSTRUCTION AT NERITA-1}

\section{Methodology}

AFTA, VR and apatite (U-Th) data provide independent but complementary constraints on the low temperature thermal histories of sedimentary rocks. The combined application of these techniques to a vertical sequence of samples (e.g. over a range of depths in an exploration well) enables quantitative determination of paleogeothermal gradients, which if caused by heating during deeper burial, can be used to estimate amounts of additional burial responsible for heating.

The methodological, analytical and interpretative aspects of AFTA, VR and apatite (U-Th)/He data are well-known (e.g. Green et al. 2002; Crowhurst et al. 2002; Japsen et al. 2007; Turner et al. 2008) and not repeated in detail here. AFTA is based on the spontaneous fission of ${ }^{238} \mathrm{U}$ atoms in apatite, and the temperaturedependent annealing of the resultant radiation damage zones (fission tracks). It can be used to define the magnitude of post-depositional heating of apatite-bearing sedimentary rocks and the timing of cooling from maximum post-depositional temperatures of up to $\sim 110^{\circ} \mathrm{C}$ (Green et al. 2002). To extract thermal history information from AFTA data we use a kinetic model that makes full quantitative allowance for the effects of $\mathrm{Cl}$ content on fission-track annealing rates (Green et al. 2002). We note that because maximum paleotemperatures are the key factor that dominates AFTA data, this technique can reveal little information on the thermal history prior to the onset of cooling. Therefore, we do not attempt to constrain the entire thermal history of each sample but focus on the key aspects of the thermal history that control the fission track age and length distribution i.e. the maximum paleotemperature of each sample and the time at which cooling from that paleotemperature began.

Extraction of thermal history information from AFTA data begins with construction of a Default Thermal History (DTH), derived from the burial history defined by the preserved sedimentary section and the present-day thermal gradient. For a sedimentary rock, this history would apply if the sample has never been any hotter than the present-day temperature at any time since deposition. If this history can explain the AFTA data, then it is not possible to extract further thermal history information. If the AFTA data show a greater degree of annealing (i.e. fission track 
age and/or track length reduction) than expected from the DTH, then the sample must have been hotter in the past and information on the magnitude and timing of heating and cooling events can be extracted from the data.

For samples that have been hotter in the past, by comparing measured AFTA parameters with values predicted from a range of possible scenarios, maximum likelihood theory (similar to that described by Gallagher (1995)) is used to define best-fit values of maximum paleotemperature and the time at which cooling begins. Systematically varying the timing of the onset of cooling and the peak paleotemperature about the best-fit values allows rigorous definition of the range of conditions giving predictions that are consistent with the measured data within $95 \%$ confidence limits for up to two (or rarely three) separate thermal episodes.

Paleotemperature estimates derived using this approach usually have an absolute uncertainty of better than $\pm 10^{\circ} \mathrm{C}$.

VR exploits the increase in reflectivity of vitrinite with temperature (Duddy et al. 1998). We utilise the model of Burnham \& Sweeney (1989) to convert values of observed maximum reflectance under oil ( $\left.R_{0} \max \right)$ to paleotemperatures. VR is highly complementary to AFTA because vitrinite is commonly found in fine-grained sedimentary rocks (apatite is generally found in sandstones) and because it can constrain maximum paleotemperatures that far exceed (i.e. $>300^{\circ} \mathrm{C}$ ), the upper limit of the AFTA technique.

Thermal histories of sediments in the $40-80^{\circ} \mathrm{C}$ range can potentially be constrained by apatite (U-Th)/He dating (Crowhurst et al. 2002). This method exploits the interplay between the accumulation of $\mathrm{He}$ within the apatite lattice by alpha decay of $U$ and Th isotopes, and the loss of He due to diffusion, which occurs at a rate dependent on temperature and grain size (Crowhurst et al. 2002). Thermal history information is extracted from (U-Th)/He data by comparing measured ages with values predicted from various thermal history scenarios in order to define the range of scenarios that give predictions that are consistent with results. Here we use the model for He diffusion developed by Farley (2000) based on laboratory diffusion studies of Durango apatite. Recent studies have highlighted discrepancies between AFTA and (U-Th)/He results that occur due to increasing He retention as the amount of radiation damage in the apatite lattice increases (Green et al. 2006). The major problem with interpretation of (U-Th)/He data in apatite derives from anomalous $\mathrm{He}$ retention due to accumulated radiation damage that give ages that are too old compared to those expected from AFTA data in the same sample (Green et al. 
2006). Anomalous He retention is not a significant issue in the interpretation of the (U-Th)/He apatite ages in this study or in previous studies integrating AFTA and (U$\mathrm{Th}$ )/He data from the Otway Basin which have yielded consistent results (House et al. 1999, 2002; Green et al. 2004).

\section{Dataset}

Nerita-1 was drilled in $74.7 \mathrm{~m}$ of water and reached a total drilled depth of $2042 \mathrm{~m}$ (bellow Kelly Bushing). It penetrated $284 \mathrm{~m}$ of the Torquay Group, $379 \mathrm{~m}$ of the Demons Bluff group, $688 \mathrm{~m}$ of the Eastern View Group and $580 \mathrm{~m}$ of the Otway Group (Eumeralla Formation), each separated by unconformities. The youngest recognised formation encountered by the well is the Miocene Puebla Formation. There are no biostratigraphic age constraints for the shallowest parts of this formation, which sampled no carbonate record younger than N Zone 8 (early Middle Miocene; Shell Development 1967) and we assume an age of $15 \mathrm{Ma}$ for the seabed unconformity at the top of the well. A single corrected BHT data point near total depth constrains the present-day geothermal gradient at this location to $\sim 31.5^{\circ} \mathrm{C} \mathrm{km}^{-1}$ (assuming a seabed temperature of $15^{\circ} \mathrm{C}$ ).

We performed AFTA on two Eumeralla Formation (Otway Group) samples (both cuttings) from depths of 1475-1542 m (sample GC628-36) and 1951-2044 m (sample GC628-19) (both true vertical depth relative to Kelly Bushing). Apatite yields were excellent in both and (U-Th)/He dating was performed on GC628-36. We supplemented these data with 14 VR samples covering a range of depths from 626 m (Anglesea Siltstone, Demons Bluff Group) to 2043 m (Eumeralla Formation).

\section{Basic results}

Fission track sample GC628-36 has a pooled fission track age of $112.5 \pm 7.1$ $\mathrm{Ma}$, and GC628-19 has a central fission track age of 116.9 $\pm 17.1 \mathrm{Ma}$ (Figure 5a, Table 1). Both fission track ages are consistent with Aptian-Albian depositional ages, whilst the broad range of $\mathrm{Cl}$ compositions in apatite grains from these samples is typical of the Eumeralla Formation (Green et al. 1986). The measured fission track ages of GC628-36 and GC628-19 are similar to those expected on the basis of the DTH, although the latter sample contains several single grain ages that are younger than expected, providing direct evidence for this sample having cooled from higher paleotemperatures in the past. The mean track lengths for samples GC628-36 and GC628-19 are $12.85 \pm 0.18 \mu \mathrm{m}$ and $11.65 \pm 0.18 \mu \mathrm{m}$, respectively. Both of these measured track lengths are shorter than expected on the basis of the DTH and can 
only be explained by these samples having experienced higher temperatures after deposition.

Measured (U-Th)/He ages from five grains from GC628-36 are plotted as a function of depth in Figure $5 b$ and $c$, together with a range of predicted ages derived from the DTH for grain radii varying from $30-125 \mu \mathrm{m}$. Three grains with radii between 60 and $125 \mu \mathrm{m}$ give measured ages $(4.4 \pm 0.13,3.6 \pm 0.13$ and $3.0 \pm 1.4 \mathrm{Ma})$ that are much younger than those predicted for these radii. This is consistent with the AFTA data from this sample, which indicate maximum post-depositional paleotemperatures higher than the present-day temperature of $\sim 59^{\circ} \mathrm{C}$ at the sample depth. Two other grains with mean radii of 33 and $50 \mu \mathrm{m}$ have measured ages (15 \pm 0.6 and $11.5 \pm 0.4 \mathrm{Ma}$ ) that are significantly older than those in the grains with radii between 60 and $125 \mu \mathrm{m}$. Since measured ages in smaller grains should be lower than in larger grains (Ehlers \& Farley 2003), we regard the older ages as anomalous and do not consider them further.

Mean VR values for the 14 samples from Nerita-1 vary from $0.26 \%$ and $0.36 \%$ in the two shallowest samples to $0.52 \%$ and $0.55 \%$ in the two samples obtained near total depth. When converted to paleotemperatures using a heating rate of $1{ }^{\circ} \mathrm{C} \mathrm{Ma}^{-1}$ and cooling rate of $10^{\circ} \mathrm{C} \mathrm{Ma}^{-1}$ it is apparent that the maximum paleotemperature estimates in the samples at depths of 626 and $1994 \mathrm{~m}$ are significantly lower than the general trend of the other measured values (Figure 6). These samples may be caved or geochemically suppressed, and are excluded from further consideration. Note that the VR data, which define a broadly linear trend that is sub-parallel to the interpreted present-day geothermal gradient, do not appear to show significant variation across the major unconformities that occur at the top of the Otway Group and the top of the Eastern View Group (Figure 6). For example, the VR samples at 700 and $733 \mathrm{~m}$ depth from the Demons Bluff Group yield $R_{0}$ max values $(0.36 \%, 0.40 \%)$ that are largely consistent with the $R_{0}$ max values of the uppermost VR samples from the Eastern View Group (e.g. $0.40 \%$ for the sample at $821 \mathrm{~m}$ ). The lack of significant variation of $R_{0}$ max values from samples that bracket the major unconformities encountered by Nerita-1 suggests that these data can be explained by one heating episode that post-dates the deposition of the youngest preserved sedimentary units that yielded VR data.

\section{Thermal history interpretation}

Modelling of AFTA parameters through a range of likely thermal histories enables constraints on the timing and magnitude of maximum paleotemperatures 
experienced by each sample to be determined. AFTA suggests that sample GC62836 (Eumeralla Formation, present-day temperature $\sim 59^{\circ} \mathrm{C}$ ) cooled from a maximum post-depositional paleotemperature of between 85 and $105^{\circ} \mathrm{C}$ at some time during the past 98 Myr (Figure 7). Similarly, sample GC628-19 (Eumeralla Formation, present-day temperature $\sim 76^{\circ} \mathrm{C}$ ) indicates cooling from maximum paleotemperatures of 95 to $110^{\circ} \mathrm{C}$ at some time between 55 and $5 \mathrm{Ma}$ (Figure 7). AFTA in this sample also allows, but does not require, paleotemperatures $>110^{\circ} \mathrm{C}$ in the period between Albian deposition (at $105 \mathrm{Ma}$ ) and $55 \mathrm{Ma}$. Paleotemperature estimates from VR samples at similar depths to the AFTA samples show excellent agreement (Figure 6). Assuming that the cooling episode identified in both samples represents a synchronous event, the overlap in timing constraints from each sample indicates onset of cooling between 55 and $5 \mathrm{Ma}$ (i.e. Eocene-Pliocene). As mentioned above, AFTA also allows but does not require, an earlier cooling episode beginning between $\sim 105$ and $55 \mathrm{Ma}$ (i.e. Albian-Paleocene). There are two important, regional unconformities in the Torquay sub-basin that fall within the 55 to $5 \mathrm{Ma}$ time range defined by AFTA. These are the mid-Eocene unconformity dated at $\sim 40-39$ Ma that separates the older Eastern View Group from the younger Demons Bluff Group (Holdgate et al. 2003), and the 10-5 Ma late Miocene-early Pliocene unconformity that separates the older Torquay Group from the younger Brighton Group (Dickinson et al. 2002). On the basis of the AFTA data alone, uplift and erosion associated with either of these unconformities could explain the observed Eocene-Pliocene cooling. However, based on the broad consistency of $R_{0}$ max values from VR samples analysed from the uppermost Eastern View Group and lowermost Demons Bluff Group (Figure 6), we interpret the cooling recorded by AFTA to be associated with the younger, late Miocene-early Pliocene unconformity.

To more precisely constrain the timing of the 55 to 5 Ma cooling episode, we refined the AFTA constraints from sample GC628-36 (i.e. post-depositional heating to $\sim 85$ to $105^{\circ} \mathrm{C}$ prior to cooling to present-day temperatures beginning between 98 and $0 \mathrm{Ma}$ ) by defining the thermal conditions within this range which predicted (U$\mathrm{Th}) / \mathrm{He}$ ages that are consistent with the three coherent single grain ages from sample GC628-36. Although the measured ages range from $4.4 \pm 0.13$ to $3.0 \pm 1.4$ $\mathrm{Ma}$, we consider acceptable predicted ages to fall in the range 6 to $2 \mathrm{Ma}$ because of potential inaccuracies in the precision of age determinations. Only thermal history scenarios involving cooling from paleotemperatures of 85 to $105^{\circ} \mathrm{C}$ beginning between 10 and 3 Ma provide predicted ages in the range of 6 to 2 Ma for grain radii 
between 60 and $125 \mu \mathrm{m}$. Figure 7 shows a representative solution with cooling from a paleotemperature of $95^{\circ} \mathrm{C}$ beginning at $8 \mathrm{Ma}$. The maximum paleotemperature required by the $(\mathrm{U}-\mathrm{Th}) / \mathrm{He}$ data is $>85^{\circ} \mathrm{C}$. Such a temperature predicts an equivalent VR level of $>0.47 \%$, consistent with mean values in adjacent VR samples $(0.49 \%$, $0.50 \%)$. The (U-Th)/He data would allow paleotemperatures $>105^{\circ} \mathrm{C}$ at $10 \mathrm{Ma}$, but AFTA results preclude this magnitude of heating. In summary, (U-Th)/He data from GC628-36 require a maximum paleotemperature of $>85^{\circ} \mathrm{C}$, consistent with AFTA results $\left(85-105^{\circ} \mathrm{C}\right)$, but constraints on the timing of cooling are far more precise (10 to $3 \mathrm{Ma}$ compared to 98 to $0 \mathrm{Ma}$ ). Combining the AFTA timing constraints from the deeper GC628-19 sample (55 to $5 \mathrm{Ma}$ ) with the (U-Th)/He constraints from GC62836 (10 to $3 \mathrm{Ma}$ ) suggests synchronous cooling of the preserved section at Nerita-1 from maximum post-depositional paleotemperatures between 10 and $5 \mathrm{Ma}$, in close correspondence with the 10 to $5 \mathrm{Ma}$ time interval recorded by the Miocene-Pliocene unconformity (Dickinson et al. 2002). These results, combined with the broad consistency of $R_{0}$ max values from samples collected from above and below the midEocene unconformity, lead us to conclude that maximum burial of the preserved Cenozoic succession at Nerita-1 occurred prior to the uplift and erosion that caused the late Miocene-early Pliocene unconformity. Although it is possible, and likely that appreciable erosion accompanied the development of the regional mid-Eocene unconformity in the Torquay sub-basin (e.g. Holdgate et al. 2003), the amount of such erosion cannot be directly constrained from our data.

A paleotemperature-depth plot shows excellent agreement between the independently determined paleotemperatures from AFTA, VR and apatite (U-Th)/He data (Figure 6). The paleotemperatures define an approximately linear paleothermal gradient that is broadly parallel to the present-day geotherm $\left(\sim 31.5^{\circ} \mathrm{C} \mathrm{km}^{-1}\right)$. The parallelism between the present-day and paleogeothermal gradients indicates that data from Nerita-1 can be interpreted in terms of heating of the preserved section by deeper burial followed by late Miocene exhumation-related cooling (cf. Green et al. 2002). Fitting a linear profile to the paleotemperatures as a function of depth allows estimation of the late Miocene paleogeothermal gradient. Extrapolation of this gradient from the top of the preserved section (i.e. the seabed) to an assumed paleosurface temperature of $15^{\circ} \mathrm{C}$ provides an estimate of the amount of additional section that was once present at this location and has been removed following late Miocene exhumation (cf. Green et al. 2002). 
Figure 8 shows the allowed values of paleogeothermal gradient and missing section required to explain the late Miocene paleotemperatures. The maximum likelihood estimate of paleogeothermal gradient is $24.5^{\circ} \mathrm{C} \mathrm{km}^{-1}$ and the allowed range of values within $95 \%$ confidence limits is 13.5 to $36.5^{\circ} \mathrm{C} \mathrm{km}^{-1}$. The allowed range of paleogeothermal gradients encompasses the present-day geotherm and confirms that heating by deeper burial is a viable explanation for the observed paleotemperatures. The maximum likelihood estimate of missing section from the top-Puebla Formation unconformity is $1700 \mathrm{~m}$, with lower and upper $95 \%$ confidence limits of 800 and $3950 \mathrm{~m}$. For a paleogeothermal gradient equivalent to the presentday gradient, between 940 and $1260 \mathrm{~m}$ of deeper burial is required to explain the observed paleotemperatures. This is our preferred range of values for the amount of now missing section removed during late Miocene-early Pliocene (10 to $5 \mathrm{Ma}$ ) exhumation. Figure 9 presents two plausible burial histories for Nerita-1; one which incorporates $1050 \mathrm{~m}$ of additional Puebla Formation deposited prior to its removal during exhumation beginning at $8 \mathrm{Ma}$, and a second, more geologically realistic scenario which also incorporates $1200 \mathrm{~m}$ of additional Eumeralla Formation that is removed during exhumation between 95 and $90 \mathrm{Ma}$, consistent with regional AFTA results (e.g. Anglesea-1; Green et al. 2004). Based on offshore and onshore evidence for a regional unconformity of mid-Eocene age (Trupp et al. 1994; Holdgate et al. 2003), it is probable that Nerita-1 experienced at least three significant exhumation episodes during the Cretaceous-Cenozoic.

\section{REGIONAL CONSTRAINTS ON THE TIMING AND MAGNITUDE OF LATE MIOCENE EXHUMATION}

Integration of AFTA, apatite (U-Th)/He and VR data from Nerita-1 provides precise constraints on the amount of erosion associated with the Miocene-Pliocene unconformity in the TSB (Figure 10). Based on extrapolation of seismic reflectors around the Nerita anticline, Dickinson et al. (2002) estimated that $\sim 400 \mathrm{~m}$ of late Miocene and younger section has been removed from this location. This value is less than half of the 940 to $1260 \mathrm{~m}$ of removed Puebla Formation estimated in this study. Typical Puebla Formation lithologies include calcareous silts, clays and marls, and grey silty marls crop out at seafloor at Nerita-1 (Abele et al. 1988). We suggest that the removed section likely comprised similar lithologies that would have proven poorly resistant to erosion and been readily removed by surface processes. The likely contrasts in average thermal conductivity between the clay-dominated removed 
section, and the more-compacted, less clay-dominated preserved section may have led us to overestimate the magnitude of removed section at Nerita-1.

We acknowledge that the thickness of eroded mid Miocene-early Pliocene sediments that our results require is much larger than the thickest known successions of preserved sediments of comparable age in the Torquay sub-basin and surrounding areas (e.g. the $\sim 400 \mathrm{~m}$ thick succession of mid-late Miocene age sediments encountered by the Nepean-37 borehole on the Nepean Peninsula; Holdgate et al. 2002). However, our higher estimate of removed mid-Miocene-early Pliocene section is broadly compatible with previous estimates for this region, as discussed below. We note that in analogous inverted basins in the British Isles such as the SW Approaches and Southern North Sea, early paleothermal and compaction studies which revealed $\mathrm{km}$-scale exhumation in wells drilled into Cenozoic compressional structures (e.g. Green 1989; Hillis 1991, 1993) were often regarded with scepticism by workers who considered the required amounts of missing section to be incompatible with the preserved stratigraphic record in these regions (e.g. Holliday 1993; Smith et al. 1994). Subsequent studies have largely confirmed the accuracy of these initial results and thus the occurrence of km-scale Cenozoic exhumation across the inverted basins of the British Isles (e.g. Green et al. 2002; Mackay \& White 2006; Hillis et al. 2008b). It is now generally acknowledged that preserved stratigraphy is not necessarily an accurate guide to determining levels of exhumation, particularly in basins that experienced regional uplift and erosion (e.g. Corcoran \& Doré 2005). Studies of inverted sedimentary basins have shown that major depocentres frequently experience an inversion of relief to become structural culminations (e.g. Hayward \& Graham 1989; Turner \& Williams 2004). Thus, the thickest original successions are often the most deeply eroded parts of inverted sedimentary basins, meaning that regions where section is preserved are not always reliable indicators as to magnitude of section that has been removed from a structural high. We suspect that this may be the case for the Nerita structure in the Torquay sub-basin.

We have used our estimate of removed section to place some constraints on late Miocene-Pliocene denudation rates in this part of the southern Australian margin. Figure 11 shows two ranges of estimates of denudation rates at Nerita-1. Both scenarios assume that exhumation began at $10 \mathrm{Ma}$, consistent with the onset of cooling recorded by AFTA and (U-Th)/He data. This allows 5 Myr for the deposition of the additional Puebla Formation and younger section, assuming a $15 \mathrm{Ma}$ age for 
the top-Puebla Formation seabed unconformity. The upper range of estimates assumes that all of the 940-1260 m of missing section was removed during the 10 to $5 \mathrm{Ma}$ interval encompassed by the Miocene-Pliocene unconformity (Figure 10), which results in denudation rates of 188-252 $\mathrm{m} \mathrm{Myr}^{-1}$. The lower range of estimates of 94-126 m Myr ${ }^{-1}$ assumes that exhumation continued to the present-day, consistent with the absence of post-15 Ma deposits at Nerita-1. Our calculated denudation rates are significantly higher than the average rates of $<10 \mathrm{~m} \mathrm{Myr}^{-1}$ estimated for southeastern Australia during the late Miocene-Pliocene by Kohn et al. (2002) using a regional apatite fission track dataset (Figure 11). They are generally consistent however with the Quaternary bedrock erosion rates of valley bottoms in the actively uplifting northern Flinders Ranges, which are calculated at 53-228 $\mathrm{m} \mathrm{Myr}^{-1}$ from cosmogenic ${ }^{10} \mathrm{Be}$ dating (Quigley et al. 2007). Sandiford (2003) estimated late Neogene-present-day tectonic uplift rates of $\sim 30-160 \mathrm{~m} \mathrm{Myr}^{-1}$ in the northern Flinders Ranges, which agrees well with the tectonic uplift rates required to explain our upper range of denudation rate estimates ( 50-65 $\mathrm{m} \mathrm{Myr}^{-1}$ ).

In Figure 12 we compile all available estimates of late Miocene-Pliocene exhumation from wells in and around the TSB. The estimates represent a combination of published (Cooper \& Hill 1997; Green et al. 2004; Holford et al. 2010) and unpublished (Cooper 1995; Geotrack International) results. Elsewhere in the TSB, Cooper (1995) estimated $\sim 600$ m of erosion at the top-Torquay Group unconformity at Snail-1 based on VR data from the Demons Bluff Group. The lower amount of section removed at Snail-1 in comparison to Nerita-1 is consistent with the lower amplitude of folding of the Cenozoic section near the latter, as observed on seismic data (Figure 13b). Our estimate of 940-1260 $\mathrm{m}$ of section removed from Nertita-1 is in good agreement with AFTA, VR and (U-Th)/He data from the nearby onshore Anglesea-1 well that indicate that $750-950 \mathrm{~m}$ of section has been removed from the top-Demons Bluff Group unconformity during exhumation which began between 12 and $7 \mathrm{Ma}$ (Green et al. 2004). This estimate is consistent with the assessment of Holdgate et al. (2001) that the mid-late Eocene (Lower Nothofagidites aspersus spore pollen zone) A Group coal seam of the uppermost Eastern View Group, which is exposed in the Anglesea coal mine has been buried to depths between $~ 500$ and $800 \mathrm{~m}$. The A Group coal seam is separated from the overlying Boonah Formation (Demons Bluff Group) by an erosional, angular unconformity, indicating some deformation and uplift in the TSB at $\sim 40-39 \mathrm{Ma}$ attributed to initial Cenozoic uplift of the Otway Ranges (Holdgate et al. 2001). Some of the $~ 500$ to 800 
$\mathrm{m}$ of missing section from the Anglesea coal mine was likely removed during midEocene exhumation (Holdgate et al. 2003), although Holdgate et al. (2001) acknowledged that much of the uplift of the Otway Ranges (and by implication, exhumation of the Anglesea coals) probably occurred in the late Miocene or later. We note that AFTA data from the Morum High (Duddy et al. 2003) and Mussel Platform (Duddy \& Erout 2001) in the offshore Otway Basin indicate an onset of deformation and uplift at those locations during the mid-Eocene, similar in timing to the age of the unconformity described by Holdgate et al. (2001) in the Anglesea coal mine and Trupp et al. (1994) offshore in the Torquay sub-basin, whilst mid-Eocene compression is also recognised in the offshore Gippsland Basin (Holdgate \& Gallagher 2003). Work is ongoing to constrain the extent and origins of this deformation, and these results will be reported elsewhere.

AFTA and VR data from wells located to the north and west of the Otway Ranges generally indicate that $>400-500 \mathrm{~m}$ of section has been removed during late Miocene-Pliocene exhumation, even at wells that are not situated on obvious structural culminations (e.g. Warracbarunah-2, Figure 13b). Fewer estimates are available for the Otway Ranges because AFTA and VR data from the outcropping Lower Cretaceous Eumeralla Formation, are dominated by thermal effects associated with mid-Cretaceous exhumation (Duddy 1994; Cooper \& Hill 1997). However, some valuable constraints are provided by VR data from the Benwerrin inlier. This isolated sequence of Paleocene (Lower Lygistepollenites balmei) coal seams and interbedded sediments occurs at a present-day topographic height of $\sim 300 \mathrm{~m}$ in the Otway Ranges (Holdgate et al. 2001). The moisture content of the brown-coal seam is the lowest (average $30 \%$ ) of any Cenozoic brown coal in Victoria (Holdgate et al. 2001) and its reflectance is high (0.40\%), indicating deeper burial by 1 to $1.5 \mathrm{~km}$ during the Cenozoic, prior to uplift and erosion (Figure 12; Cooper \& Hill 1997), probably during both the mid-Eocene and late Miocene-early Pliocene.

\section{SEISMIC CONSTRAINTS ON THE MODE OF INTRAPLATE DEFORMATION}

To identify the processes responsible for the late Miocene-Pliocene exhumation we conducted structural mapping of $2 \mathrm{D}$ seismic reflection profiles from the TSB and north of the Otway Ranges. The TSB seismic data are from the PGS Southern Australian Margin Digital Atlas (SAMDA) project. We supplemented these offshore data with several additional onshore profiles located to the northwest of the Otway Ranges provided by DPI Victoria. 
Structural and stratigraphic mapping of seismic data reveals a consistent picture of folding of shallow post-rift Oligocene-Miocene sedimentary sequences due to reverse-reactivation of deeper syn-rift normal faults within the CretaceousPaleogene succession under horizontal compression, resulting in structural geometries highly characteristic of tectonic inversion (Williams et al. 1989, 2005; Holford et al. 2009b). This tectonic style is best demonstrated by a seismic profile that ties the Nerita-1 and Snail-1 wells (Figure 13b). The $\sim$ NE-SW-trending Nerita Anticline is the major structure in the basin, and has formed as a consequence of reverse reactivation of several of the normal faults that accommodated deposition of the Otway Group and Eastern View Group (as witnessed by growth of these sequences towards the major NNW-dipping fault that underlies Nerita-1, Figure 13b). A seismic profile acquired across the Wild Dog-1 well reveals a very similar structural style (Figure 13c). Regional mapping of the early Oligocene base Jan Juc Formation marker horizon shows that the Nerita Anticline has a maximum amplitude of $\sim 0.5 \mathrm{~s}$ two-way travel time (TWTT), compared with $\sim 0.35 \mathrm{~s}$ for the Snail Anticline which has lower structural relief (consistent with the observation of higher exhumation at Nerita1 compared to Snail-1) (Figure 12). The preserved Torquay Group appears conformable and is uniformly affected by deformation confirming a late MiocenePliocene timing for deformation and exhumation (Dickinson et al. 2002).

Seismic reflection profiles obtained to the north of the Otway Ranges indicate similar styles of intraplate deformation to those observed in the TSB (Figure 13a; modified after Constantine \& Lieberman (2001), see Hill et al. (1995) for alternative interpretation of this composite section). These data show minor folding of Cenozoic sediments in the Colac Trough caused by reverse reactivation of NNW-dipping Jurassic-Cretaceous normal faults, and major deformation towards the Otway Ranges at the SSE end of the section, where the thick Cretaceous depocentre has been uplifted to form a structural high, partly accommodated by reverse displacement on the major SSE-dipping fault (Figure 13a).

We note that AFTA and VR data from the Warracbarunah-2 well, located near the NNW end of Figure 13a, indicate that $\sim 400 \mathrm{~m}$ of section has been removed from the top-Heytesbury Group (late Miocene?) unconformity (Geotrack unpublished data), despite few obvious signs of compressional deformation around this well. One explanation for this background level of exhumation is that crustal shortening is accommodated by reverse slip on normal faults that was not sufficient to displace their null points (the arbitrary point of change from net-normal to net-reverse 
displacement along a contractionally-reactivated normal fault) downwards (cf. Williams et al. 1989; Holford et al. 2009b). Although we do not rule out a contribution from mantle-driven dynamic uplift (e.g. Sandiford \& Quigley 2009), we suggest that much of the exhumation associated with the Miocene-Pliocene unconformity in apparently 'uninverted' settings around SE Australia may be caused by small increments of crustal shortening. Such shortening can be achieved by processes that include reversal of motion on normal faults, horizontal compaction of the fine-grained lithologies, and sub-seismic scale reverse faulting that are generally difficult to recognise on seismic reflection profiles (Holford et al. 2009b). If crustal shortening were the sole driving mechanism of this exhumation, then $\sim 6-8 \%$ shortening of a crustal column $30 \mathrm{~km}$ thick could account for the observed maximum thicknesses of missing section (calculated using equations 3-5 of Brodie \& White (1995) and parameters used therein).

Another notable feature of Figure 13a is the major unconformity between the Cretaceous and Cenozoic successions of the Colac Trough. Truncated reflections beneath this unconformity, planed-off fault blocks and a syncline to the NNW of the major SSE-dipping fault that bounds the Otway Ranges (cf. Hill et al. 1995), all attest to an additional phase of significant deformation prior to deposition of the Cenozoic succession. Regional AFTA results and data from specific wells such as Anglesea-1 indicate that up to $3 \mathrm{~km}$ of Otway Group and older rocks were removed during exhumation that accompanied this deformation and began between 100 to $95 \mathrm{Ma}$ (Duddy 2003; Green et al. 2004). The fact that the Otway Ranges and surrounding areas have been subject to several phases of major deformation and exhumation over the past 100 Myr points to the question as to what factors have localised intraplate deformation in this part of the Australian continent.

\section{DISCUSSION}

The southeastern part of the southern Australian continental margin has been undergoing mild intraplate deformation since at least the late Miocene-early Pliocene (10 to 5 Ma; Dickinson et al. 2002; Sandiford et al. 2004). We have shown that exhumation associated with the regional ( $1500 \mathrm{~km}$ wide) unconformity that marks the probable inception of this phase of ongoing tectonic activity locally exceeds $1 \mathrm{~km}$ in the TSB, and that deformation and exhumation in this part of the margin has been largely accomplished by reactivation of syn-rift normal faults under horizontal compression. 
Many of the late Miocene-present-day faults and anticlines in the TSB and adjacent areas strike broadly NE-SW (Figure 14). Present-day stress orientations determined in the Otway Basin indicate NW-SE oriented $\left(\sim 125^{\circ} \mathrm{N}\right)$ maximum horizontal stress $\left(\mathrm{S}_{\mathrm{Hmax}}\right)$ (Nelson et al. 2006), orthogonal to the strike of the structures (Figure 14). Likewise, the broadly N-S strike directions of Quaternarypresent-day faults in the Flinders and Mt Lofty Ranges are consistent with the observed $\sim \mathrm{E}-\mathrm{W}\left(082^{\circ} \mathrm{N}\right)$ sub-horizontal maximum principal stress determined from inversions of earthquake focal mechanisms (which are mostly reverse/strike-slip) (Clark \& Leonard 2003).

The origins of the present-day stress field in southeastern Australia and the Australian continent are generally well understood (Hillis \& Reynolds 2000). Platescale stress modelling incorporating the heterogeneous-nature of the convergent northern and eastern boundaries of the Indo-Australian Plate has shown that present-day stress orientations in the Australian continent are consistent with a firstorder control by plate-boundary forces (Reynolds et al. 2002, 2003; Hillis et al. 2008a). Sandiford et al. (2004) postulated that increased coupling between the Pacific and Australian plates resulting from the growth of the Southern Alps in New Zealand (beginning between $\sim 12-6 \mathrm{Ma}$ ) was a critical factor in the initiation of the present-day stress field of southeastern Australia, whose origins similarly trace back to 10-5 Ma (Figure 10). Dickinson et al. (2002) also pointed out the correlation between the onset of deformation in southeast Australia and a change in plate motion at $\sim 12$ to $10 \mathrm{Ma}$ along the convergent northern boundary between the Australian and Pacific plates which resulted in $\sim 4.5 \mathrm{~km}$ of uplift and $\sim 3 \mathrm{~km}$ of exhumation of the Papua New Guinea Mobile Belt (Hill \& Raza 1999). A key insight from the finite element modelling performed by Reynolds et al. $(2002,2003)$ is that state of stress at any point within a plate is a controlled by the net torques of all the boundary forces that act on the plate. Therefore, the late Miocene modifications of the Australian-Pacific plate boundaries are likely to have resulted in plate-wide stress reorganisations. The correlation between these events and the late Miocene onset of deformation in southeast Australia implies that transitions between different plate boundary-controlled stress regimes, exerts a key control on the timing and distribution of intraplate deformation (cf. Sandiford et al. 2004).

Late Miocene-Pliocene intraplate deformation and resultant uplift and erosion in the TSB and Otway and Flinders Ranges commonly involves reactivation of favourably oriented pre-existing structures under a compressional stress regime that 
is controlled by distant plate boundary interactions. Holdgate et al. (2008) have recently presented high-resolution Shuttle Radar Terrain Model (STRM) images from the southeastern Highlands of Australia that reveal extensive ENE-trending faults that displace Cenozoic volcanic and sedimentary paleovalley infills. Holdgate et al. (2008) suggest that displacement along these faults is partly responsible for the postEocene uplift of the East Victoria Highlands. Many authors have argued for predominantly Cretaceous uplift of the southeastern Highlands and lesser amounts of Cenozoic uplift (Wellman 1987), but significant post-Eocene uplift is indicated by the presence of late Eocene (Middle N. Aspersus zone) mudstones that outcrop at 1723 $m$ asl at Hotham Heights, which contain paleoflora indicating deposition at altitudes of 150-800 m (Holdgate et al. 2008).

The ENE-trending faults of the southeastern Highlands (e.g. Kosciusko Fault, Dargo Fault, Mt Beauty Fault) are highly consistent with the trends of late MiocenePliocene structures in the TSB and adjacent areas (Figure 14). Likewise, inversions of earthquake focal mechanisms in the southeastern Highlands (Snowy Mountains) by Clark \& Leonard (2003) indicate a pure NW-SE compressive stress regime for this region (maximum principal stress azimuth $=315^{\circ} \mathrm{N}$ ) (Figure 14). Given the above observations, we consider it plausible that late Miocene-Pliocene reversemovements on ENE-trending faults have contributed at least several hundred metres to uplift in the southeastern Highlands, following earlier Cenozoic uplift during the Eocene-Oligocene revealed by AFTA data (Duddy 2009).

Whilst reactivation of pre-existing structures under a favourable stress regime can explain much of the late Miocene-Pliocene intraplate deformation in southeastern Australia, the cause of repeated uplift and deformation of particular parts of southeastern Australian margin over the past 100 Myr, such as the Otway Ranges, remains an outstanding problem. The Otway Ranges experienced up to $\sim 1$ $\mathrm{km}$ of exhumation since the late Miocene-Pliocene, and as much as $\sim 3 \mathrm{~km}$ during the mid-Cretaceous (100-95 Ma; Duddy 2003; Green et al. 2004), with both phases of exhumation largely caused by reverse-reactivation of normal faults under horizontal compression (Hill et al. 1995).

A possible explanation for the repeated localisation of deformation in the Otway Ranges relies on the radiogenic character of the thick Eumeralla Formation succession that forms the ranges. The Eumeralla Formation consists of fine-medium grained volcanogenic sandstones whose maximum proven present-day thickness of $\sim 3 \mathrm{~km}$ is constrained by the Fergusons Hill-1 well; thicker sections are interpreted to 
be present offshore (Duddy 2003). A considerably thicker succession in the past is inferred from AFTA data, which indicate that an additional $\sim 3 \mathrm{~km}$ of section was removed from locations such as the Anglesea-1 and Olangolah-1 wells (Duddy 1994; Green et al. 2004) whilst as much as $\sim 5 \mathrm{~km}$ of additional Eumeralla Formation section may have been removed from Cape Otway (Duddy 2003). Whole rock geochemistry data and mineral assemblages indicate that the Eumeralla Formation contains relatively high potassium contents (characteristic of dacitic continental volcanic suites) (Duddy 2003). Sandiford (1999) has shown that the burial of basin fills characterised by appreciable heat production following rifting can raise Moho temperatures and result in significant long-term lithospheric weakening (as much as $5 \%$ per $\mathrm{km}$ of basin fill) if the lower crust is initially strong prior to basin formation. We propose that the early Cretaceous burial of the radiogenic Eumeralla Formation succession now exposed in the Otway Ranges led to long-term thermal weakening of that part of the southern Australian margin, which acted to localise intraplate deformation during periods when horizontal stresses were relatively high (i.e. during the mid-Cretaceous and late Miocene-present). Thus, whilst the ultimate driving force for the ongoing intraplate deformation of the southern Australian margin is almost certainly plate boundary forces transmitted into the plate interior, it appears as though the thermal structure of the crust exerts a major control on the distribution of resultant lithospheric failure.

\section{CONCLUSIONS}

The southeastern part of the southern Australian continental margin contains a rich record of late Miocene-present intraplate deformation. This mild deformation is responsible for the most recent major uplift and erosion of the Otway Ranges and folding of Cenozoic sediments in the TSB, and its onset is marked by a regional unconformity that can be traced for $\sim 1500 \mathrm{~km}$ within the basins of the southeast Australian margin. Previous studies using seismic reflection data have suggested that the amount of exhumation recorded by this unconformity in the TSB is $\sim 400 \mathrm{~m}$, but paleothermal (AFTA, VR and apatite (U-Th)/He) data from the Nerita-1 and Anglesea-1 wells indicate that the preserved mid-Miocene and older section at that location has been more deeply buried by up to $1 \mathrm{~km}$. Thermal history interpretation of these data suggests that exhumation-related cooling began between 10 and $5 \mathrm{Ma}$, which closely corresponds to the 10-5 Ma time gap represented by the regional late Miocene-Pliocene unconformity. Our exhumation estimate for Nerita-1 is similar to previous exhumation estimates based on paleothermal data from the Otway Ranges, 
confirming that growth of the Otway Ranges to their present elevations largely occurred after the late Miocene, despite this region also having experienced major uplift and deformation during the mid-Cretaceous. Seismic reflection profiles from the TSB and Otway Ranges show that late Miocene-Pliocene deformation and exhumation has been largely accomplished by reactivation of syn-rift normal faults under horizontal compression, which has resulted in the observed folding of Cenozoic post-rift sediments. The paleostress orientations inferred from late Miocene-Pliocene structures are consistent with independent determinations of the present-day stress field, as is the case for other regions of active intraplate deformation like the Flinders Ranges and southeastern Highlands, which implicates plate boundary forces as the primary driving mechanism of deformation. In particular, the late Miocene onset of deformation and exhumation is coeval with significant changes in the nature of the boundaries surrounding the Indo-Australian plate (e.g. increased coupling of the Australian-Pacific plate boundary associated with formation of the Southern Alps in New Zealand). This observation implies that changes in intraplate stress states resulting from plate boundary-reorganisations exert a key control on episodes of intraplate deformation and uplift.

\section{ACKNOWLEDGMENTS}

ARC Discovery Project DP0879612 supported this work. We thank Adam Smith and Huw Edwards of PGS and Terry Smith of DPI Victoria for provision of seismic data, and reviewers Guy Holdgate and Julie Dickinson for their helpful and constructive comments. We also thank SMT for provision of their Kingdom Suite seismic interpretation software. This publication represents TRaX Record 133. MSS publishes with the permission of the Executive Director, British Geological Survey (NERC).

\section{REFERENCES}

Abele C., Gloe C. S., Hocking J. B., Holdgate G. R., Kenley P. R., Lawrence C. R., Ripper D., Threfall W. F. \& Bolger P. F. 1988. Tertiary. In: Douglas J. G. \& Ferguson J. A. Eds. The Geology of Victoria (2 ${ }^{\text {nd }}$ edition), pp. 252-350. Geological Society of Australia, Victorian Division, Melbourne.

BieRMAN P. R. \& CAFFEE M. 2002. Cosmogenic exposure and erosion history of Australian bedrock landforms. GSA Bulletin 114, 787-803.

Braun J., Burbidge D. R., Gesto F. N., Sandiford M., Gleadow A. J. W., Kohn B. P. \& CUMmings P. R. 2009. Constraints on the current rate of deformation and 
surface uplift of the Australian continent from a new seismic database and lowT thermochronological data. Australian Journal of Earth Sciences 56, 99-110. BRODIE J. \& WHITE N. 1995. The link between sedimentary basin inversion and igneous underplating. In: Buchanan J. G. \& Buchanan P. G. eds. Basin Inversion, pp. 21-38. Geological Society Special Publication 88.

BURNHAM A. K. \& SWEENEY J. J. 1989. A chemical kinetic model of vitrinite reflectance maturation. Geochimica et Cosmochimica Acta 53, 2649-2657.

CÉlÉRIER J., SANDIFORd M., HANSEN D. L. \& QUiGley M. 2005. Modes of active intraplate deformation, Flinders ranges, Australia. Tectonics 24, 10.1029/2004TC001679.

CLARK D. \& MCCUE K. 2003. Australian paleoseismology: towards a better basis for seismic hazard estimation. Annals of Geophysics 46, 1087-1105.

CLARK D. J. \& LEONARD M. 2003. Principal stress orientations from multiple focalplane solutions: new insight into the Australian intraplate stress field. In: Hillis R. R. \& Müller R. D. eds. Evolution and Dynamics of the Australian Plate, pp. 91-105. Geological Society of Australia Special Publication 22 and Geological Society of America Special Paper 372.

COOPER G. T. 1995. Structural geology, thermochronology, and tectonic evolution of the Torquay embayment-eastern Otway Basin. PhD thesis, Monash University, Australia (unpubl.).

COOPER G. T. \& HilL K. C. 1997. Cross-section balancing and thermochronological analysis of the Mesozoic development of the eastern Otway Basin. APPEA Journal 37, 390-414.

Constantine A. E. \& LiBERMAN N. 2001. Hydrocarbon prospectivity package for VIC/O-01(1), VIC/O-01(2) and VIC/O-01(3), eastern onshore Otway Basin, Victoria, Australia: 2001 acreage release. Victoria Initiative for Minerals and Petroleum Report 70.

Corcoran D. V. \& DorÉ A. G. 2005. A review of techniques for the estimation of magnitude and timing of exhumation in offshore basins. Earth-Science Reviews 72, 129-168.

Crowhurst P. V., Green P. F. \& KamP P. J. J. 2002. Appraisal of (U-Th)/He apatite thermochronology as a thermal history tool for hydrocarbon exploration: an example from the Taranaki Basin, New Zealand. AAPG Bulletin 86, 18011819. 
Dickinson J. A., Wallace M. W., Holdgate G. R., Daniels J., Gallagher S. J. \& THOMAS L. 2001. Neogene tectonics in SE Australia: implications for petroleum systems. APPEA Journal 41, 37-52.

Dickinson J. A., Wallace M. W., Holdgate G. R., Gallagher S. J. \& Thomas L. 2002.

Origin and timing of the Miocene-Pliocene unconformity in southeast Australia. Journal of Sedimentary Research 72, 288-303.

Doré A. G., Corcoran D. V. \& Scotchman I. C. 2002. Prediction of the hydrocarbon system in exhumed basins, and application to the NW European margin. In: Doré A. G., Cartwright J. A., Stoker M. S., Turner J. P. \& White N. eds. Exhumation of the North Atlantic margin: timing, mechanisms and implications for petroleum exploration, pp. 401-429. Geological Society of London Special Publication 196.

DuDDY I. R. 1994. The Otway Basin: thermal, structural and tectonic and hydrocarbon generation histories. In: Finlayson D. M. ed. Extended abstracts, NGMA/PESA Otway Basin Symposium, Melbourne, 20 April 1994, pp. 35-42. Record of the Australian Geological Survey Organisation 1999/14.

DUDDY I. R. 2003. Mesozoic, a time of change in tectonic regime. In: Birch W. D. ed. Geology of Victoria, pp. 239-286. Geological Society of Australia Special Publication 23.

DudDY I. R. 2009. Origin of the Australian Highlands. In: Norvick M. S. \& Gallagher S. J. eds. Origin of the Australian Highlands, Selwyn Symposium of the GSA Victoria Division, September 2009, pp. 71-78. Geological Society of Australia Extended Abstracts 94.

DUDDY I. R. \& EROUT B. 2001. AFTA ${ }^{\circledR}$ calibrated 2D modelling of hydrocarbon generation and migration using Temispack ${ }^{\circledR}$ : preliminary results from the Otway Basin. In: Hill K. C. \& Bernecker T. eds. Eastern Australian Basin Symposium, pp. 485-497. Petroleum Exploration Society of Australia Special Publication.

Duddy I. R., Erout B., Green P. F., Crowhurst P. V. \& Boult P. J. 2003. Timing constraints on the structural history of the western Otway Basin and implications for hydrocarbon prospectivity around the Morum High, South Australia. APPEA Journal 43, 59-83.

Duddy I. R., Green P. F., Hegarty K. A., Bray R. J. \& O'brien G. W. 1998. Dating and duration of fluid flow events determined using $\mathrm{AFTA}^{\circledR}$ and vitrinite reflectancebased thermal history reconstruction. In: Parnell J. ed. Dating and Duration of 
Hot Fluid Flow Events and Fluid-Rock Interaction, pp. 41-51. Geological Society Special Publication 144.

EHLERS T. A. \& FARLEY K. A. 2003. Apatite (U-Th)/He thermochronometry: methods and applications to problems in tectonics and surface processes. Earth and Planetary Science Letters 206, 1-14.

FARLEY K. A. 2000. Helium diffusion from apatite: General behaviour as illustrated by Durango fluorapatite. Journal of Geophysical Research 105B, 2903-2914.

FARLEY K. A., WOLF R. A. \& SILVER L. T. 1996. The effects of long alpha-stopping distances on (U-Th)/He ages. Geochimica et Cosmochimica Acta 60, 42234229.

GalbRaith R. F. \& LASLETT G. M. 1993. Statistical methods for mixed fission track ages. Nuclear Tracks 21, 459-470.

GALLAGHER K. 1995. Evolving temperature histories from apatite fission-track data. Earth and Planetary Science Letters 136, 421-435.

GeOtRack InTERnAtIONAL RePORT \#761R. Eastern onshore Otway Basin.

GREEN P. F. 1989. Thermal and tectonic history of the East Midlands shelf (onshore UK) and surrounding regions assessed by apatite fission track analysis. Journal of the Geological Society, London 146, 755-773.

Green P. F., Crowhurst P. V. \& DUdDY I. R. 2004. Integration of AFTA and (UTh)/He thermochronology to enhance the resolution and precision of thermal history reconstruction in the Anglesea-1 well, Otway Basin, SE Australia. In: Boult P. J., Johns D. R. \& Lang S. C. eds. Eastern Australian Basins Symposium II, pp. 117-131. Petroleum Exploration Society of Australia Special Publication.

Green P. F., Crowhurst P. V., Duddy I. R., JaPsen P. \& Holford S. P. 2006. Conflicting (U-Th)/He and fission track ages in apatite: Enhanced He retention, not anomalous annealing behaviour. Earth and Planetary Science Letters 250, 407-427.

Green P. F., Duddy I. R. \& Bray R. J. 1995. Applications of thermal history reconstruction in inverted basins. In: Buchanan J. G. \& Buchanan P. G. eds. Basin Inversion, pp. 148-165. Geological Society Special Publication 88.

Green P. F., Duddy I. R., Gleadow A. J. R., Tingate P. R. \& Laslett G. M. 1986. Thermal annealing of fission tracks in apatite 1. A qualitative description. Chemical Geology 59, 237-253. 
Green P. F., Duddy I. R. \& Hegarty K. A. 2002. Quantifying exhumation in sedimentary basins of the UK from apatite fission track analysis and vitrinite reflectance data: precision, accuracy and latest results. In: Doré A. G., Cartwright J. A., Stoker M. S., Turner J. P. and White N. eds. Exhumation of the North Atlantic Margin: Timing, Mechanisms and Implications for Petroleum Exploration, pp. 331-354. Geological Society Special Publication 196.

HaYWARD A. B. \& GRAHAM R. H. 1989. Some geometrical characteristics of inversion. In: Cooper M. A. \& Williams G. D. eds. Inversion Tectonics, pp. 17-39. Geological Society Special Publication 44.

HILl K. C. \& RAZA A. 1999. Arc-continent collision in Papua New Guinea: Constraints from fission track thermochronology. Tectonics 18, 950-966.

Hill K. C., Hill K. A., Cooper G .T., O'Sullivan A. J., O'Sullivan P. B. \& Richardson M. J. 1995. Inversion around the Bass Basin, SE Australia. In: Buchanan J. G. \& Buchanan P. G. eds. Basin Inversion, pp. 525-547. Geological Society Special Publication 88.

HILLIS R. R. 1991. Chalk porosity and Tertiary uplift, Western Approaches Trough, SW UK and NW French continental shelves. Journal of the Geological Society, London 148, 669-679.

HILLIS R. R. 1993. Tertiary erosion magnitudes in the East Midlands Shelf, onshore UK. Journal of the Geological Society, London 150, 1047-1050.

HILLIS R. R. \& REYNOLDS S. D. 2000. The Australian stress map. Journal of the Geological Society 157, 915-921.

Hillis R. R., Holford S. P., Green P. F., Doré A. G., Gatliff R. W., Stoker M. S., Thomson K., Turner J. P., Underhill J. R. \& Williams G. A. 2008b. Cenozoic Exhumation of the southern British Isles. Geology 36, 371-374.

Hillis R. R., SANDIFORd M., ReYNolds S. D. \& Quigley M. C. 2008a. Present-day stress, seismicity and Neogene-to-Recent tectonics of Australia's 'passive' margins: intraplate deformation controlled by plate boundary forces. In: Johnson H., Doré A. G., Gatliff R. W., Holdsworth R., Lundin E. R. \& Ritchie J. D. eds. The nature and origin of compression in passive margins, pp. 71-90. Geological Society Special Publication 306.

Holdgate G. R. \& GallagheR S. J. 2003. Tertiary, a period of transition to marine basin environments. In: Birch W. D. ed. Geology of Victoria, pp. 289-335. Geological Society of Australia Special Publication 23. 
Holdgate G. R., Gallagher S. J. \& Wallace M. W. 2002. Tertiary coal geology and stratigraphy of the Port Phillip Basin, Victoria. Australian Journal of Earth Sciences 49, 437-453.

Holdgate G. R., Rodriguez C., Johnstone E. M., Wallace M. W. \& Gallagher S. J. 2003. The Gippsland Basin top Latrobe unconformity, and its expression in other SE Australia basins. APPEA Journal 43, 149-173.

Holdgate G. R., Smith T. A. G., Gallagher S. J. \& Wallace M. W. 2001. Geology of coal-bearing Palaeogene sediments, onshore Torquay Basin, Victoria.

Australian Journal of Earth Sciences 48, 657-679.

Holdgate G. R., Wallace M. W., Gallagher S. J., Wagstaff B. E. \& Moore D. 2008.

No mountains to snow on: major post-Eocene uplift of the East Victoria highlands; evidence from Cenozoic deposits. Australian Journal of Earth Sciences 55, 211-234.

Holford S. P., Green P. F., Duddy I. R., Turner J. P., Hillis R. R. \& Stoker M. S. 2009a. Regional intraplate exhumation episodes related to plate boundary deformation. GSA Bulletin 121, 1611-1628.

Holford S. P., Hillis R. R., Duddy I. R., Green P. F., Tuitt A. K. \& Stoker M. S. 2010. Impacts of Neogene-Recent compressional deformation and uplift of hydrocarbon prospectivity of the passive southern Australian margin. APPEA Journal 50, 267-285.

Holford S. P., Turner J. P., Green P. F. \& Hillis R. R. 2009b. Signature of cryptic sedimentary basin inversion revealed by shale compaction data in the Irish Sea, western British Isles. Tectonics 28, TC4011, doi:10.1029/2008TC002359.

HOLLIDAY D. W. 1993. Mesozoic cover over northern England: interpretation of apatite fission track data. Journal of the Geological Society, London 150, 657-660.

House M. A., FARLEY K. A. \& KoHN B. P. 1999. An empirical test of helium diffusion in apatite: borehole data from the Otway basin, Australia. Earth and Planetary Science Letters 170, 463-474.

House M. A., Kohn B. P., FARLEY K. A. \& RAZA A. 2002. Evaluating thermal history models for the Otway Basin, southeastern Australia, using (U-Th)/He and fission-track data from borehole apatites. Tectonophysics 349, 277-295.

HURFord A. J. H. \& GREEN P. F. 1983. The zeta age calibration of fission-track dating. Chemical Geology (Isotope Geoscience Section) 1, 285-317.

Japsen P., Green P. F., Nielsen L. N., Rasmussen E. S. \& Bidstrup T. 2007. Mesozoic-Cenozoic exhumation events in the eastern North Sea Basin: a 
multi-disciplinary study based on palaeothermal, palaeoburial, stratigraphic and seismic data. Basin Research 19, 451-490.

Kohn B. P., Gleadow A. J. W., Brown R. W., Gallagher K., O'Sullivan P. B. \& FOSTER D. A. 2002. Shaping the Australian crust over the last 300 million years: insights from fission track thermotectonic imaging and denudation studies of key terranes. Australian Journal of Earth Sciences 49, 697-717.

LEONARD M. 2008. One hundred years of earthquake recording in Australia. Bulletin of the Seismological Society of America 98, 1458-1470.

MACKAY L. M. \& WHITE N. J. 2006. Accurate estimates of the spatial pattern of denudation by inversion of stacking velocity data: An example from the British Isles. Geochemistry Geophysics Geosystems 7, Q10007, doi:10.1029/2005GC001192.

McGowran B., Holdgate G. R., LI Q. \& Gallagher S. J. 2004. Cenozoic stratigraphic succession in southeastern Australia. Australian Journal of Earth Sciences 51, 459-496.

Mclaren S., Wallace M. W., Gallagher S. J., Dickinson J. A. \& McAllister A. 2009. Age constraints on Oligocene sedimentation in the Torquay Basin, southeastern Australia. Australian Journal of Earth Sciences 56, 595-604.

Messent B. E., Collins G. I. \& West B. G. 1999. Hydrocarbon prospectivity of the offshore Torquay sub-basin, Victoria: gazettal area V99-1. Victoria Initiative for Minerals and Petroleum Report 60.

Nelson E. J., Hillis R. R., SANdiford M., Reynolds S. D. \& Mildren S. D. 2006. Present-day state-of-stress of southeast Australia. APPEA Journal 46, 283305.

NORVICK M. S. \& SMITH M. A. 2001. Mapping the plate tectonic reconstruction of southern and southeastern Australia and implications for petroleum systems. APPEA Journal 41, 15-35.

QUIGLEY M., CUPPER M. \& SANDIFORD M. 2006. Quaternary faults of southern Australia: palaeoseismicity, slip rates and origin. Australian Journal of Earth Sciences 53, 285-301.

Quigley M., SANDiford M., Fitfield K. \& Alimanovic A. 2007. Bedrock erosion and relief production in the northern Flinders Ranges, Australia. Earth Surface Processes and Landforms 32, 929-944.

REYNoldS S. D., Coblentz D. D. \& Hillis R. R. 2002. Tectonic forces controlling the regional intraplate stress field in continental Australia: results from new finite- 
element modelling. Journal of Geophysical Research 107B, 10.1029/2001JB000408.

ReYNolds S. D., Coblentz D. D. \& Hillis R. R. 2003. Influences of plate-boundary forces on the regional intraplate stress field of continental Australia. In: Hillis R. R. \& Müller R. D. eds. Evolution and Dynamics of the Australian Plate, pp. 5970. Geological Society of Australia Special Publication 22 and Geological Society of America Special Paper 372.

SANDIFORD M. 1999. Mechanics of basin inversion. Tectonophysics 305, 109-120.

SANDIFORD M. 2003. Neotectonics of southeastern Australia: linking the Quaternary faulting record with seismicity and in situ stress. In: Hillis R. R. \& Müller R. D. eds. Evolution and Dynamics of the Australian Plate, pp. 107-119. Geological Society of Australia Special Publication 22 and Geological Society of America Special Paper 372.

SANDIFORD M. \& EGHOLM D. L. 2008. Enhanced intraplate seismicity along continental margins: some causes and consequences. Tectonophysics 457, 197-208.

SANDIFORD M. \& QUIGLEY M. 2009. TOPO-OZ: Insights into the various modes of intraplate deformation in the Australian continent. Tectonophysics 474, 405416.

SANDIFORD M., QUIGLEY M., De BrokeRT P. \& JAKICA S. 2009. Tectonic framework for the Cenozoic cratonic basins of Australia. Australian Journal of Earth Sciences $56, \mathrm{~S} 5-\mathrm{S} 18$.

SANDiford M., Wallace M. \& Coblentz D. 2004. Origin of the in situ stress field in southeastern Australia. Basin Research 16, 325-38.

SHELL DeVELOPMENT 1967. Nerita No. 1, offshore Victoria well completion report. Shell Development (Australia) Pty Ltd (unpublished).

Smith K., Gatliff R. W., Smith N. J. P. \& Hillis R. R. 1994. Discussion on the amount of Tertiary erosion in the UK estimated using sonic velocity analysis. Journal of The Geological Society, London 151, 1041-1044.

Trupp M. A., SPEnCE K. W. \& Gidding M. J. 1994. Hydrocarbon prospectivity of the Torquay Sub-Basin, Offshore Victoria. APEA Journal 34, 479-494.

TURNER J. P. \& WILLIAMS G. A. 2004. Sedimentary basin inversion and intra-plate shortening. Earth-Science Reviews 65, 277-304.

Turner J. P., Green P. F., Holford S. P. \& LAWrence S. R. 2008. Thermal history of the Rio Muni (West Africa)-NE Brazil margins during continental breakup. Earth and Planetary Science Letters 270, 354-367. 
Wallace M. W., Dickinson J. A., Moore D. H. \& SAndiford M. 2005. Late Neogene strandlines of southern Victoria: a unique records of eustasy and tectonics in southeast Australia. Australian Journal of Earth Sciences 52, 277-295.

WeLLMAN P. 1987. Eastern Highlands of Australia: their uplift and erosion. BMR Journal of Australian Geology \& Geophysics 10, 277-286.

Williams G. A., TURNER J. P. \& Holford S. P. 2005. Inversion and exhumation of the St. George's Channel basin, offshore Wales, UK. Journal of the Geological Society 162, 97-110.

Williams G. D., Powell C. M. \& CoOper M. A. 1989. Geometry and kinematics of inversion tectonics. In: Cooper M. A. \& Williams G. D. eds. Inversion Tectonics, pp. 3-15. Geological Society Special Publication 44.

\section{FIGURE CAPTIONS}

Figure 1 Map showing boundaries of the Indo-Australian plate and the state of stress within the Australian continent (modified after Reynolds et al. 2003). Large black arrows indicate mid-ocean ridge forces, small black arrows indicate forces associated with continental collision and subduction zones, white arrows indicated buoyancy forces resulting from lithospheric density variations, grey arrows indicate mean maximum horizontal stress orientations with the Australian continent (length of bars is proportional to data quality). H, Himalaya; S, Sumatra Trench; J, Java Trench; B, Banda Arc, NG, New Guinea; SM, Solomon Trench; NH, New Hebrides; LHR, Lord Howe Rise; TK, TongaKermadec Trench; NZ, New Zealand; SNZ, south of New Zealand; MOR, midocean ridge; cb, collisonal boundary; sz, subduction zone; ia, island arc.

Figure 2 Torquay sub-basin location map showing main locations, wells and seismic lines used or referred to in this study and extent of surface outcrop of the Lower Cretaceous Eumeralla Formation.

Figure 3 Simplified stratigraphic columns for the eastern Otway Basin and Torquay sub-basin (modified after Constantine \& Lieberman 2001).

Figure 4 Seismic reflection profiles (and accompanying interpretations) from the Torquay sub-basin illustrating the character of the late Miocene-Pliocene 
unconformity. Seismic profiles provided by PGS. (a) Line OS90A-43. (b) Line 040-11.

Figure 5 (a) Fission track age and mean track length data for samples from Nerita-1 plotted against depth and present temperature (based on a seabed temperature of $15^{\circ} \mathrm{C}$ and present-day geothermal gradient of $\left.31.5^{\circ} \mathrm{C} \mathrm{km}^{-1}\right)$. The variation in stratigraphic age with depth is shown as are variations in fission track ages predicted from the DTH for a range of apatite compositions (from left to right 0 $0.1,0.4-0.5,0.9-1.0$ and $1.5-1.6 \mathrm{wt} \% \mathrm{Cl}$ groups). (b) Apatite (U-Th)/He ages for individual aliquots from sample GC628-36 plotted against depth. Errors on individual measured ages are within the area of the symbols. Measured (UTh)/He ages are compared with the range of ages predicted for the DTH for a range of grain radii. Measured ages of three aliquots with grain radii between 60 and $125 \mu \mathrm{m}$ are coherent and much less than the predicted ages for these radii, indicating that maximum paleotemperatures were higher than the present temperature of $59^{\circ} \mathrm{C}$ at this depth. (c) Comparison of predictions for a representative thermal history solution that is also compatible with AFTA results for this sample, with cooling from $95^{\circ} \mathrm{C}$ beginning at $8 \mathrm{Ma}$. Overall, the apatite (U-Th)/He dating results require cooling from 85 to $105^{\circ} \mathrm{C}$ began at some time between 10 and $3 \mathrm{Ma}$.

Figure 6 Paleotemperatures derived from AFTA, VR and apatite (U-Th)/He data in the Nerita-1 well plotted against depth and the estimated present-day geothermal gradient. Integration of AFTA, VR and apatite (U-Th)/He results suggests that the entire drilled section began to cool from maximum paleotemperatures that were significantly higher than present-day temperatures. The gradient of the paleotemperature profile at the time of maximum paleotemperatures is similar to the present-day geothermal gradient $\left(31.5^{\circ} \mathrm{C} \mathrm{km}^{-1}\right)$ suggesting that the probable cause of heating was deeper burial with cooling due to uplift and erosion. Several of the paleotemperatures estimated from the VR data plot below the trend of the majority of the VR and AFTA results. This may be due to caving contamination (as noted by the VR analyst for the deeper samples) or suppression of the true VR levels. These data have thus been excluded from our quantitative analyses.

Figure 7 Schematic illustration of the thermal history of the Nerita- 1 well, derived from the AFTA and apatite (U-Th)/He results in samples GC628-36 (light grey box) and GC628-19 (dark grey box). Light grey shaded field shows 
paleotemperature and time constraints from apatite (U-Th)/He dating in sample GC628-36. Integration of all results indicates a common time of cooling beginning between 10 and $5 \mathrm{Ma}$. Note that the AFTA results allow, but do not require, cooling associated with mid-Cretaceous and Eocene unconformities, as shown by the dashed paths for each sample.

Figure 8 Ranges of amounts of section removed from the top-Puebla Formation unconformity and paleogeothermal gradients (hyperbolic ellipsoid) required to explain the paleotemperatures estimated from AFTA, apatite (U-Th)/He and selected VR data. The hyperbolic ellipsoid defines the parameter ranges estimated from AFTA that are consistent with the respective paleotemperature constraints within $95 \%$ confidence limits. The black dot indicates the maximum likelihood solution values of paleogeothermal gradient $\left(24.5^{\circ} \mathrm{C} \mathrm{km}^{-1}\right)$ and removed section $(1.7 \mathrm{~km})$. For a paleogeothermal gradient of $31.5^{\circ} \mathrm{C} \mathrm{km}^{-1}$, equal to the present-day gradient, between 0.94 and $1.26 \mathrm{~km}$ of removed section is required on the top-Puebla Formation unconformity in order to honour the paleotemperature constraints.

Figure 9 Reconstructed burial histories for Nertita-1. (a) Burial history reconstructed on the basis of the preferred thermal history reconstruction for this well (e.g. Figure 7). The grey vertical column represents the 10 to $5 \mathrm{Ma}$ constraints on the onset of cooling. This burial history incorporates $1050 \mathrm{~m}$ of additional section attributed to the Miocene Puebla Formation whose removal by uplift and erosion begins at $8 \mathrm{Ma}$ (any time between 10 and $5 \mathrm{Ma}$ is allowed by the data) and is completed prior to the Pliocene. The underlying thermal history utilises a constant geothermal gradient of $31.5^{\circ} \mathrm{C} \mathrm{km}^{-1}$. In this scenario, the preserved Cretaceous-Miocene section at Nerita-1 attains maximum post-depositional burial depths and paleotemperatures prior to late Cenozoic exhumation. (b) Alternative burial history reconstructed on the basis of regional AFTA results, which we believe to be more geologically realistic. This burial history includes the same late Miocene event shown in (a), but also incorporates $1200 \mathrm{~m}$ of additional Eumeralla Formation that is removed during exhumation between 95 and $90 \mathrm{Ma}$. This history employs a geothermal gradient that increases from $31.5^{\circ} \mathrm{C} \mathrm{km}^{-1}$ at $140 \mathrm{Ma}$ to $51^{\circ} \mathrm{C} \mathrm{km}^{-1}$ at $95 \mathrm{Ma}$, and subsequently declines back to $31.5^{\circ} \mathrm{C} \mathrm{km}^{-1}$ at $80 \mathrm{Ma}$ and remains constant to the present-day. This history is more consistent with regional AFTA results (e.g. Anglesea-1; Green et al. 2004), which show evidence for elevated geothermal gradients prior to mid- 
Cretaceous exhumation that removed upwards of $1 \mathrm{~km}$ of section from the Eumeralla Formation.

Figure 10 Chronostratigraphic chart for the Neogene of SE Australian basins (modified after Abele et al. 1988 and Dickinson et al. 2001) indicating the lateral extent of the late Miocene-early Pliocene unconformity, compared with temporal constraints on the timing of cooling from AFTA and apatite (U-Th)/He data from Nerita-1 and major contemporaneous tectonic events across SE Australia and the Indo-Australian plate (Dickinson et al. 2002).

Figure 11 Comparison of published Cretaceous and Cenozoic denudation rates from SE Australia; estimated 10 to $5 \mathrm{Ma}$ and 10 to $0 \mathrm{Ma}$ denudation rates estimated from Nerita-1 data (this study), Quaternary denudation rates for the Flinders Ranges (Quigley et al. 2007) and the Eyre Peninsula (Bierman \& Caffe 2002) from cosmogenic ${ }^{10} \mathrm{Be}$ concentrations, and long-term (100 to $0 \mathrm{Ma}$ ) denudation rates estimated from apatite fission-track data from the eastern Highlands (Kohn et al. 2002).

Figure 12 Compilation of late Miocene-early Pliocene exhumation estimates and structures with evidence for late Miocene-Pliocene activity in the Torquay subbasin and the eastern Otway Basin. Isochrons (twtt (s)) of base Oligocene Jan Juc Formation derived from seismic mapping offshore Torquay sub-basin also shown. Exhumation estimates based on this study, Cooper (1995), Cooper \& Hill (1997), Holdgate et al. (2001), Green et al. (2004), Holford et al. (2010) and unpublished Geotrack International reports.

Figure 13 Seismic profiles illustrating late Miocene-Pliocene deformation in the Torquay sub-basin and eastern Otway Basin. (a) Interpreted and uninterpreted seismic profiles OGF91A-03 (left) and OGF92A-411 (right) acquired over the Colac Trough and the northern Otway Ranges. Modified after Constantine \& Lieberman (2001) but see Hill et al. (1995) for alternative interpretation of this composite section. Seismic profiles provided by DPI Victoria. (b) Interpreted and uninterpreted seismic profile O40-21A that ties exploration wells Nerita-1 and Snail-1 in the Torquay sub-basin. (c) Interpreted and uninterpreted seismic profile OS90A-13 that intersects the Wild Dog-1 exploration well. Seismic profiles provided by PGS.

Figure 14 Compilation map showing regional seismicity and state of stress in southeast Australia. Structures with evidence for Neogene activity shown in white modified after Hillis et al. (2008a) and Holdgate et al. (2008). Regional 
$\mathrm{S}_{\mathrm{Hmax}}$ trends and stress trajectories modified after Hillis \& Reynolds (2000), regional stress tensors determined from multiple earthquake focal mechanisms for the Flinders Ranges and Snowy Mountains modified after Clark \& Leonard (2003), as are P-axis orientations from isolated focal mechanisms. Note the general consistency between the independently determined stress orientations, and paleostress orientations inferred from faults and anticlines with observed Neogene activity.

Table 1 AFTA, VR and apatite (U-Th)/He sample details, data and paleotemperature analysis summary for Nerita-1. 
Table 1 AFTA, VR and apatite (U-Th)/He sample details, data and palaeotemperature analysis summary for Nerita-1.

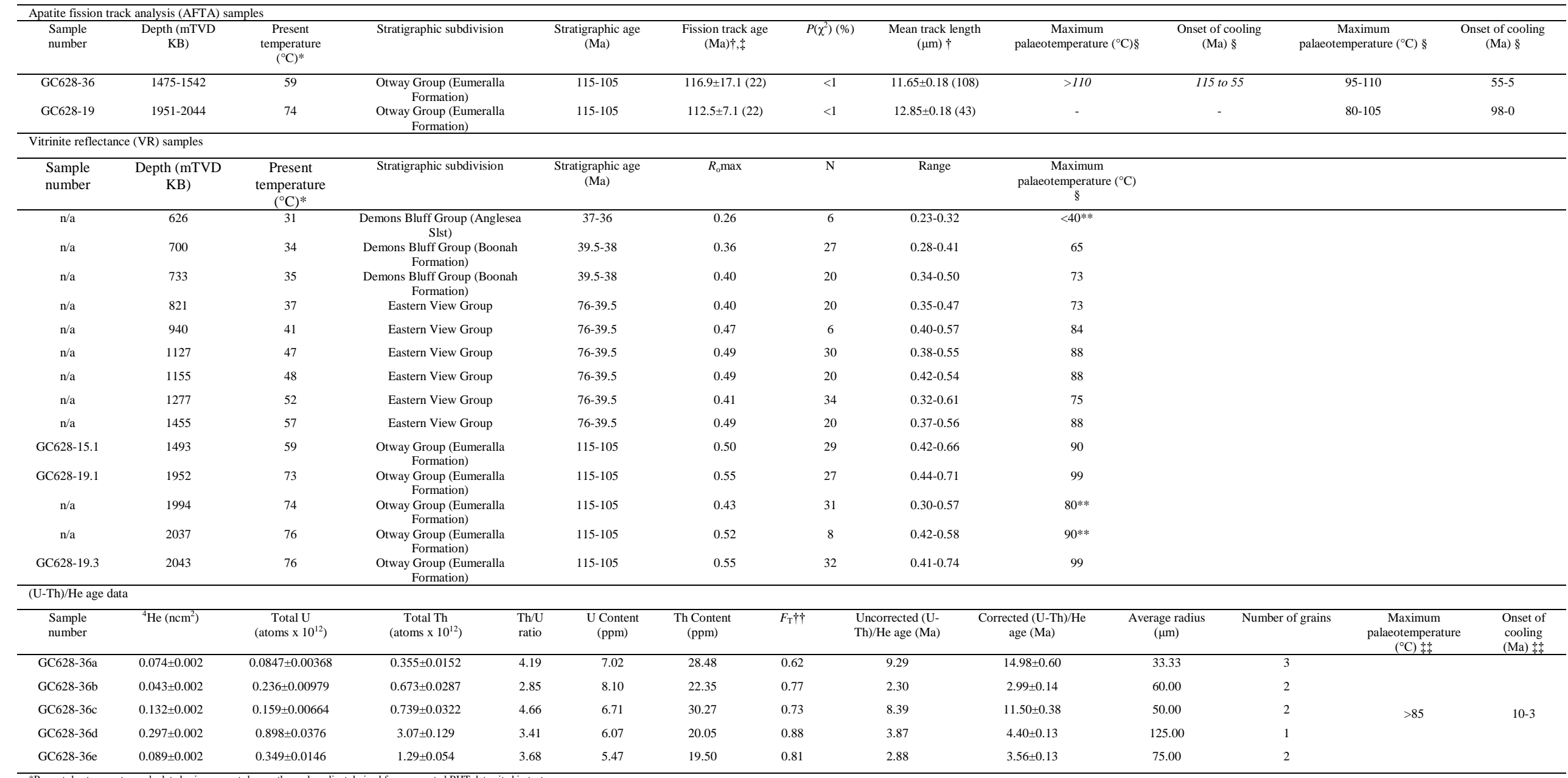

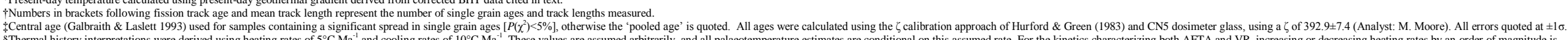

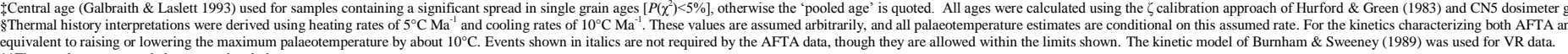

** These values are regarded as anomalously low:

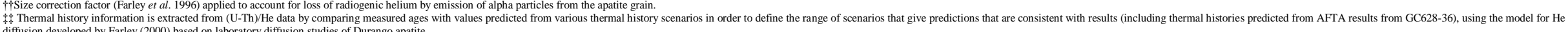


Holford et al Figure 1

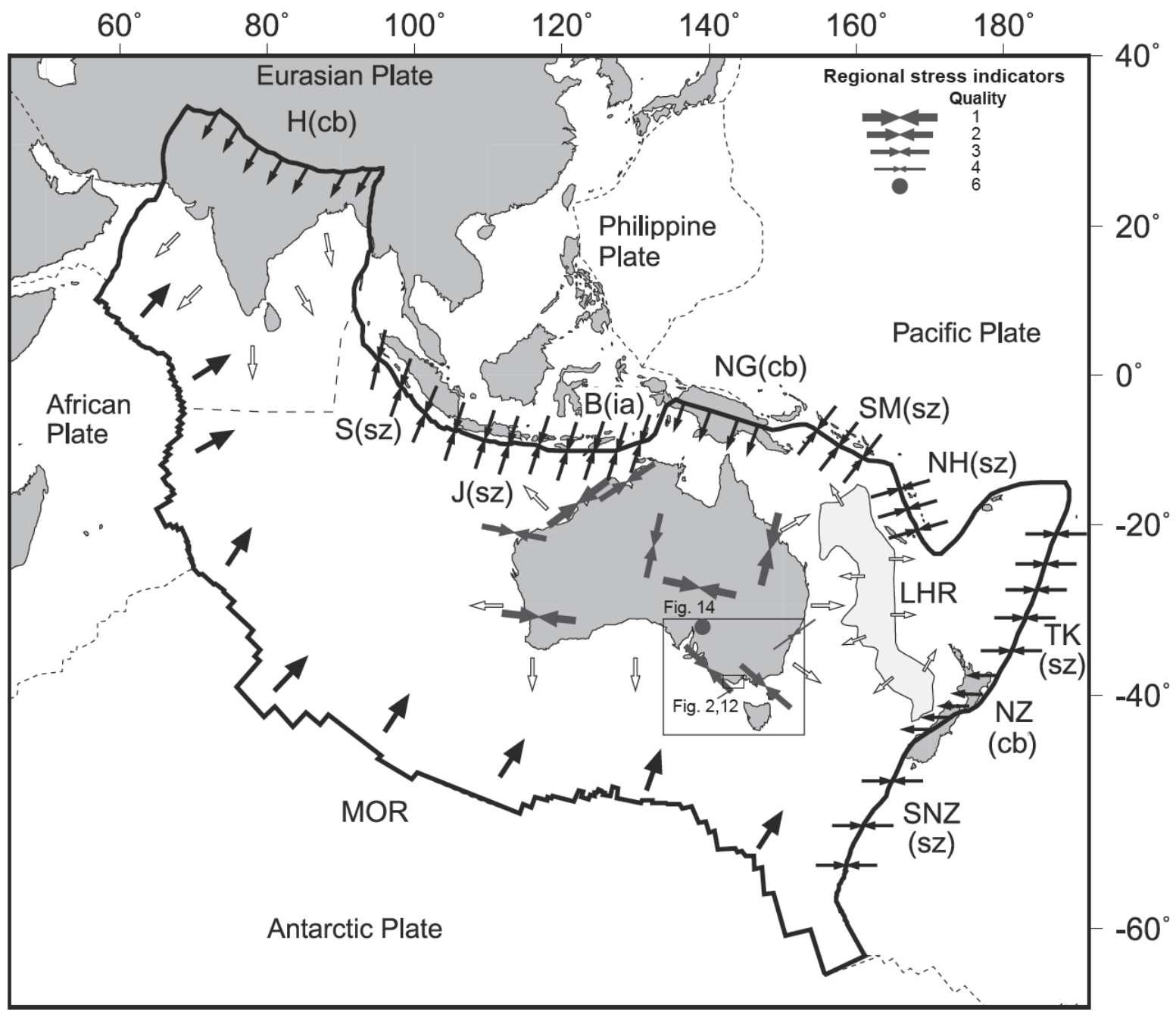


Holford et al Figure 2

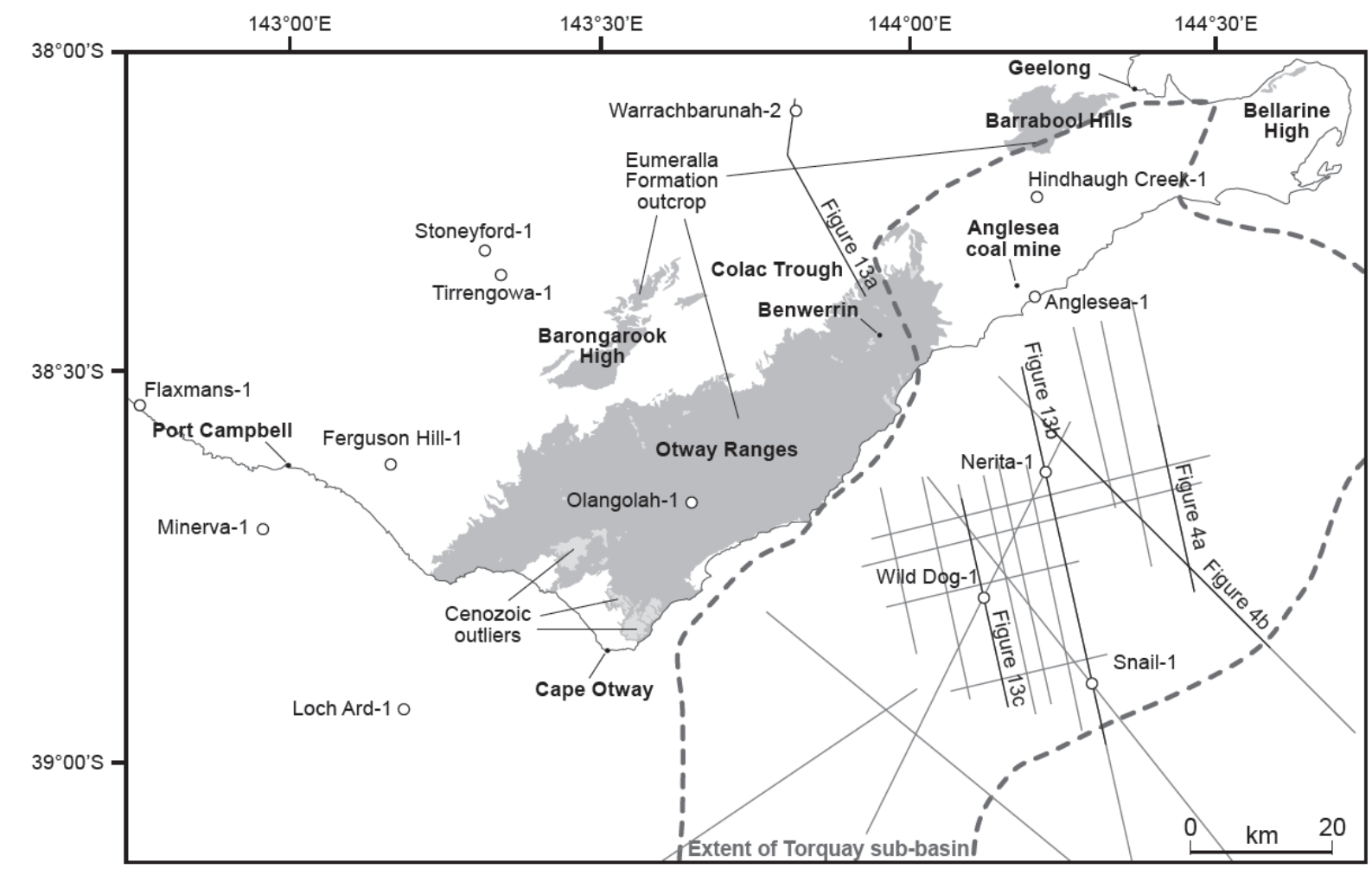




\section{Holford et al Figure 3}

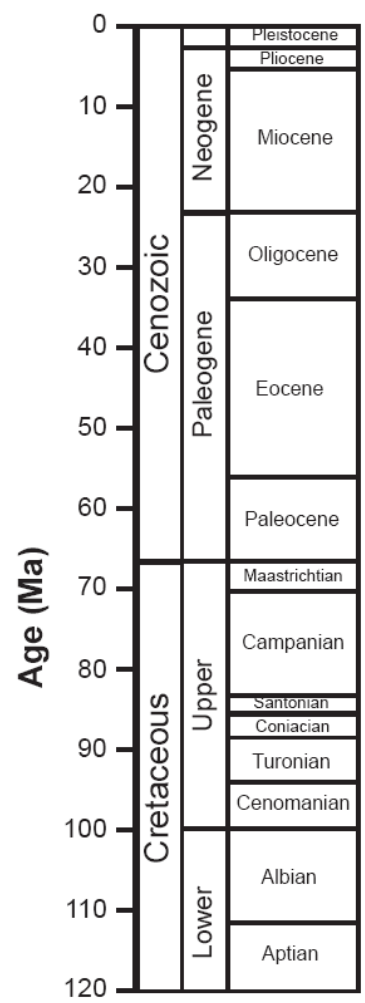

Shipwreck | Colac Otway Trough Trough Ranges

Hanson Plain Sand/Newer Volcanics

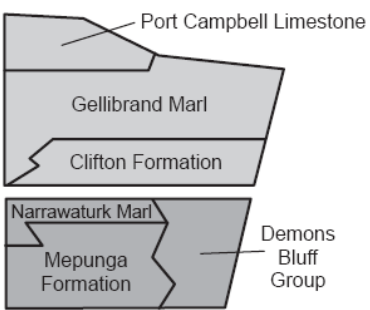

GROUP

\section{WANGERRIP} GROUP

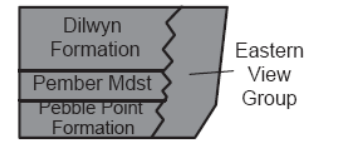
SHERBROOK
GROUP

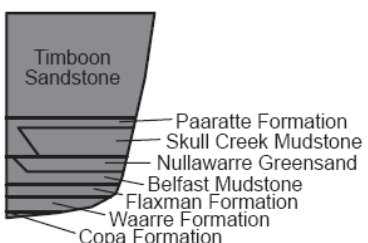

Copa Forre Formation
BRIGHTON GROUP
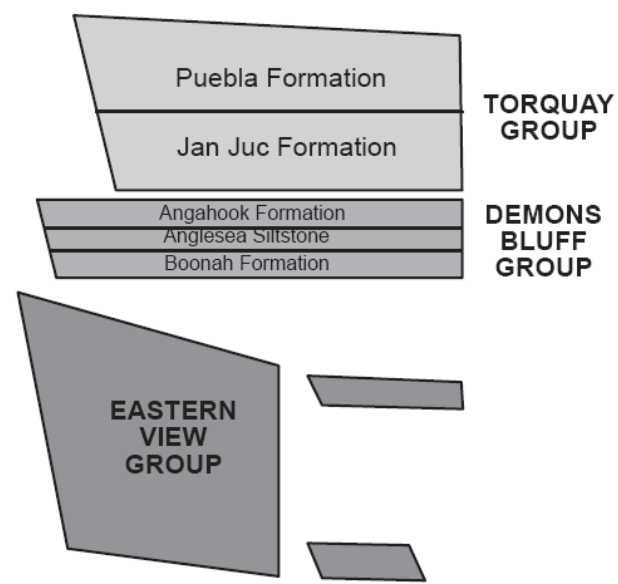

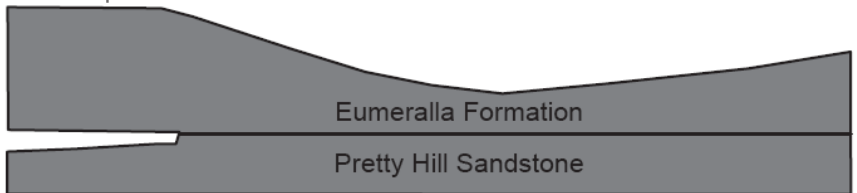




\section{Holford et al Figure 4}
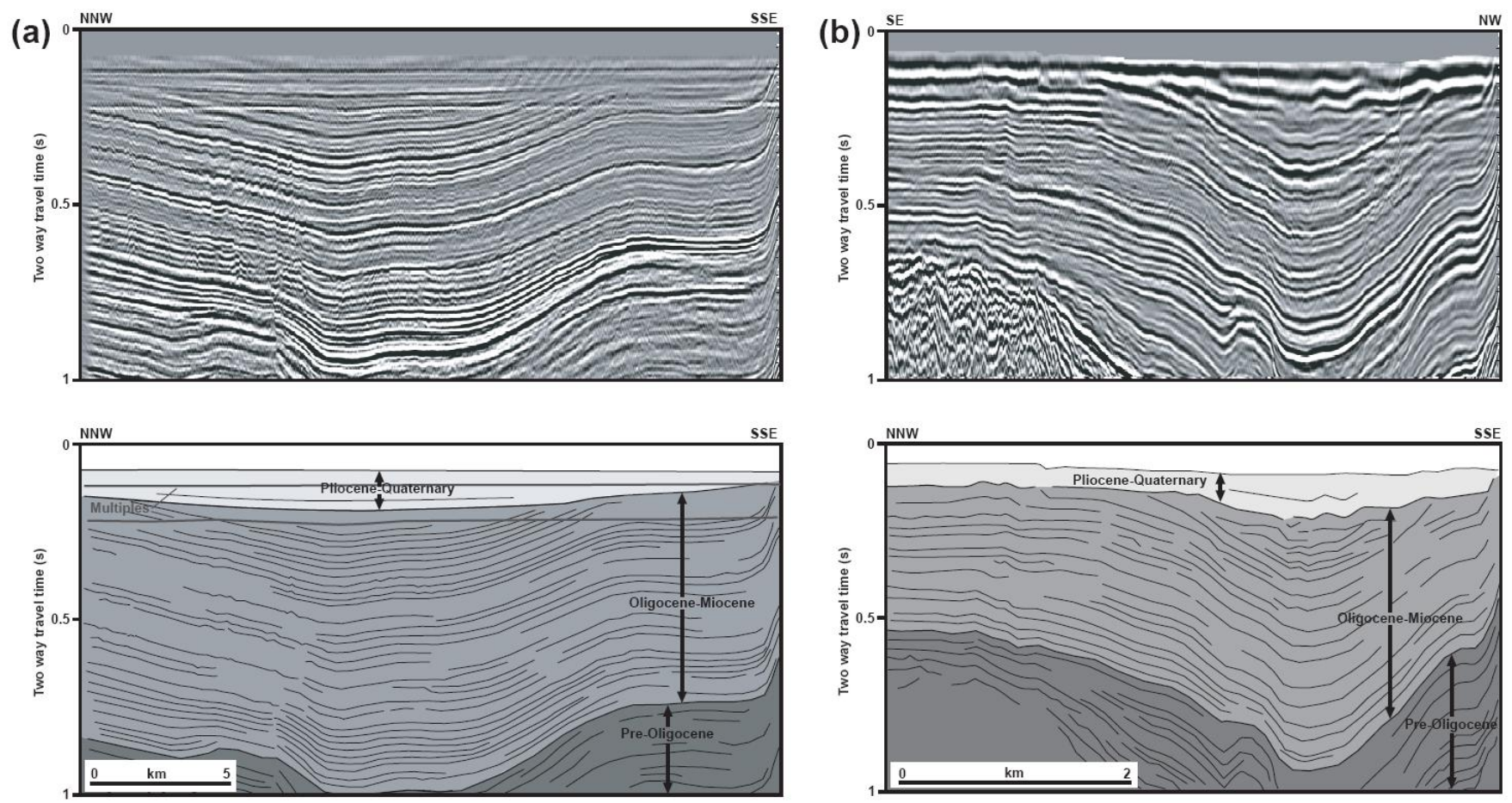


\section{Holford et al Figure 5}

(a)

(b)

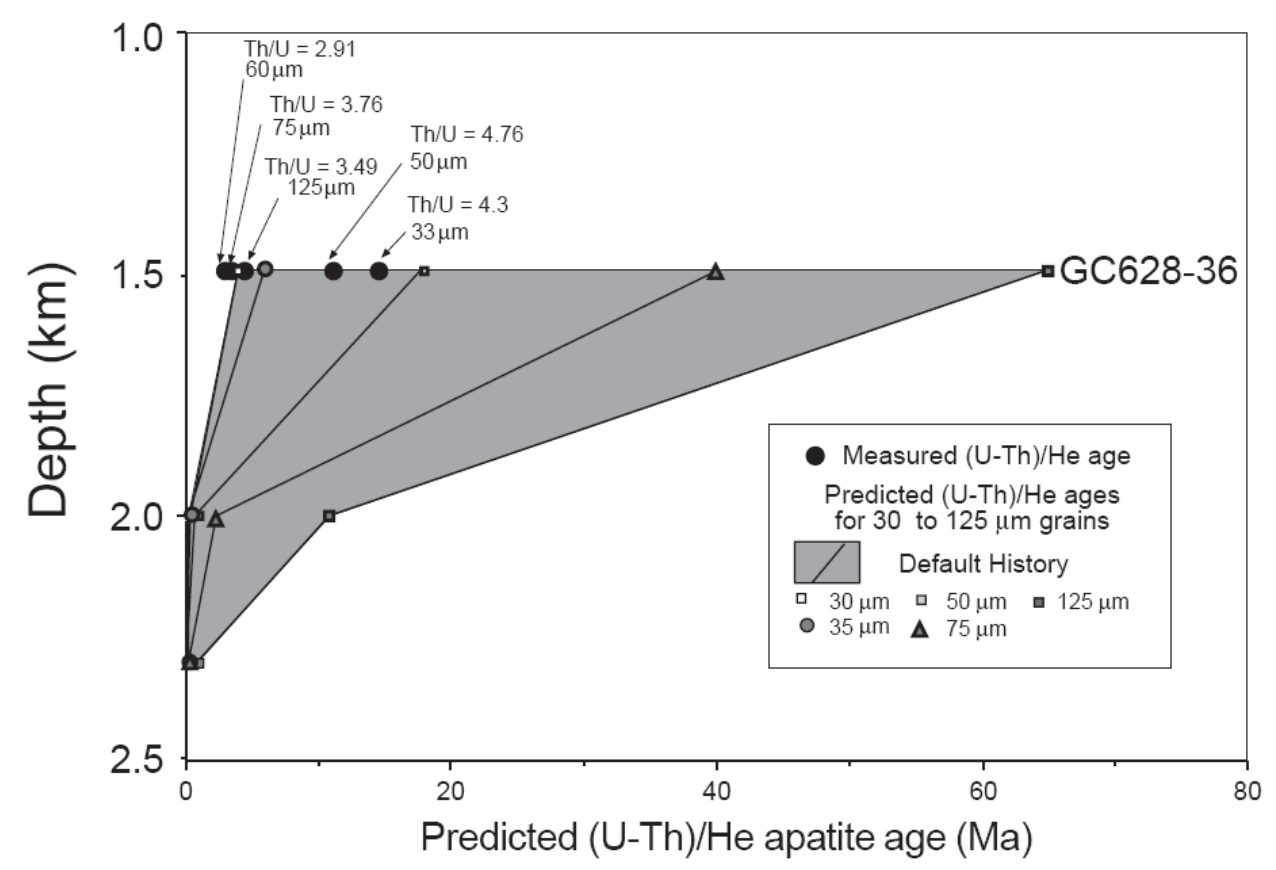

(c)

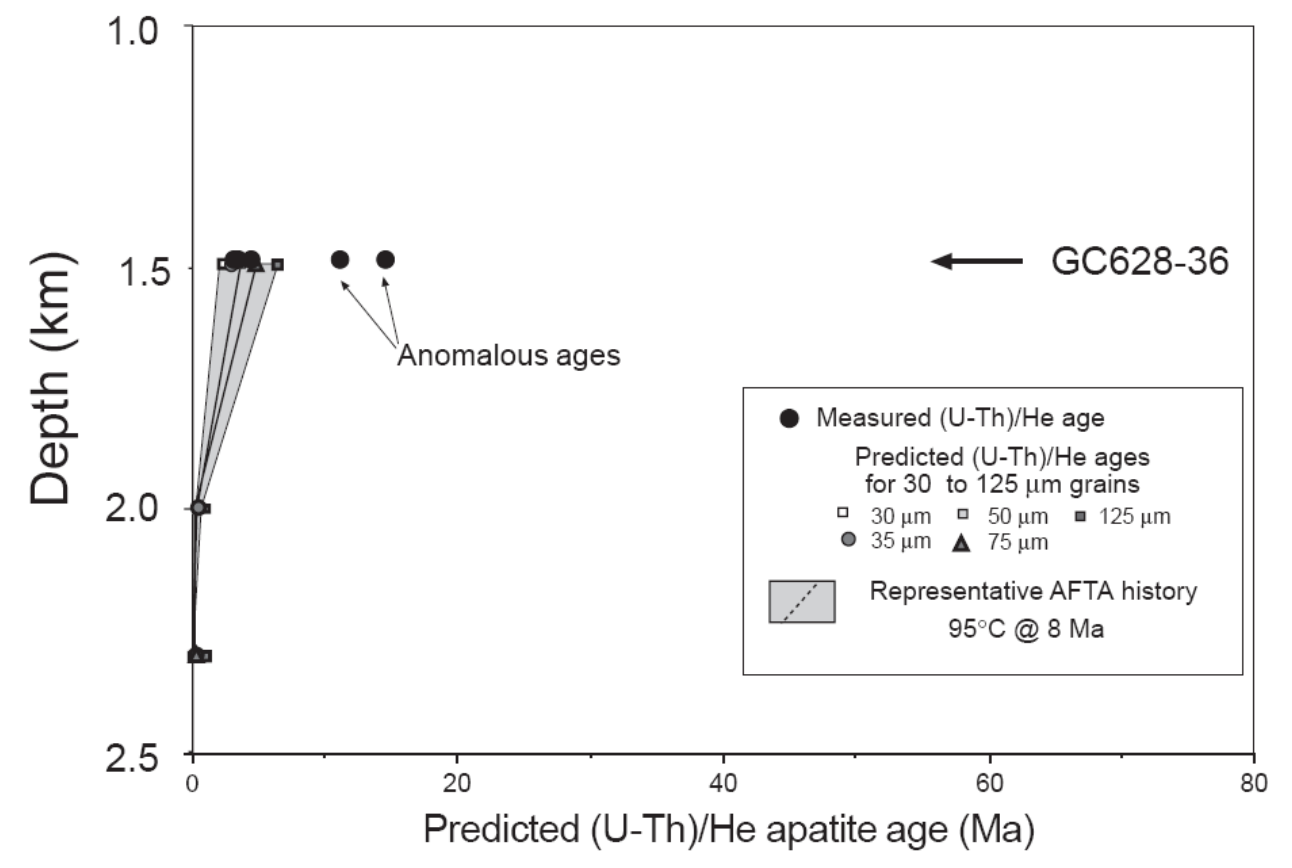

bKB

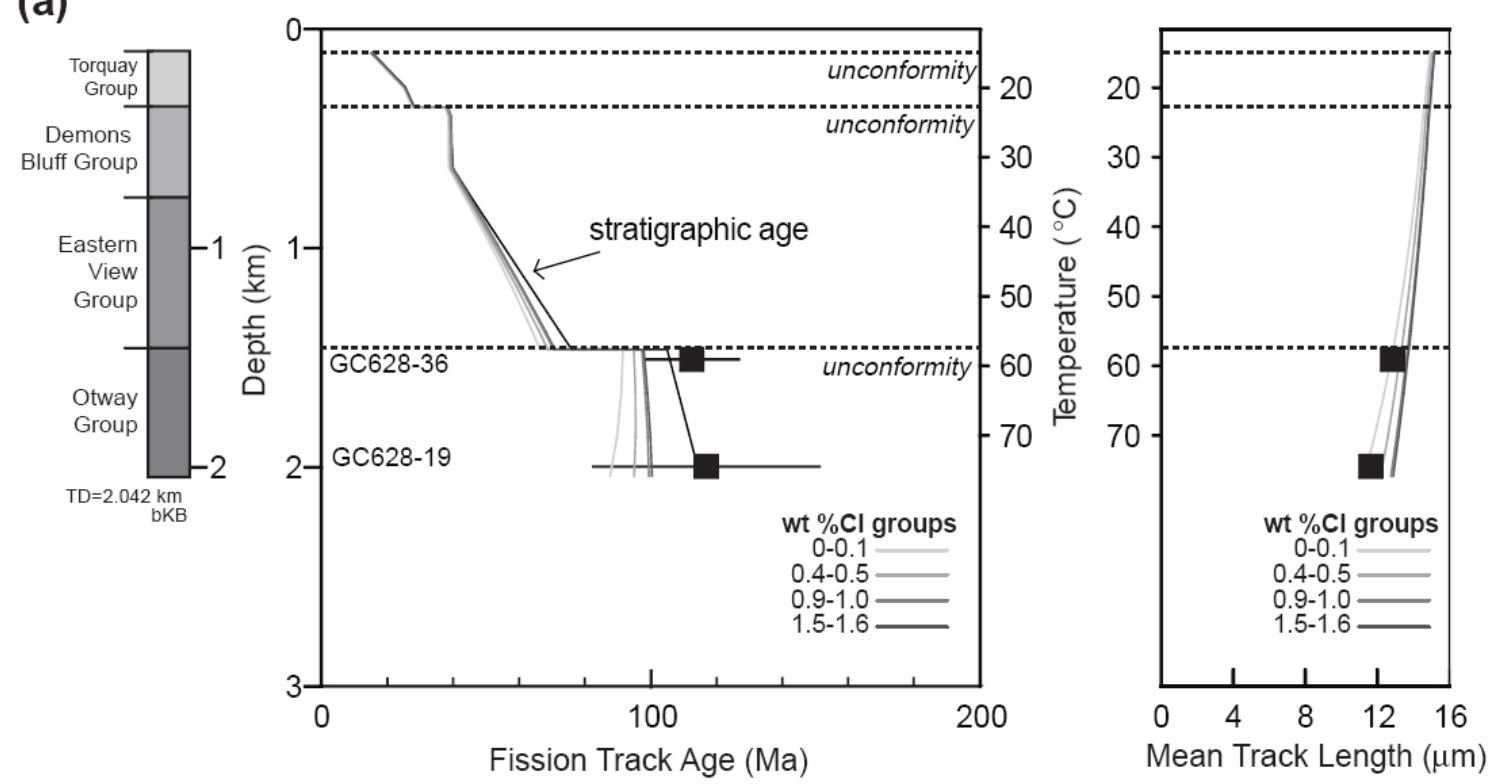

Mean Track Length $(\mu \mathrm{m})$ 


\section{Holford et al Figure 7}

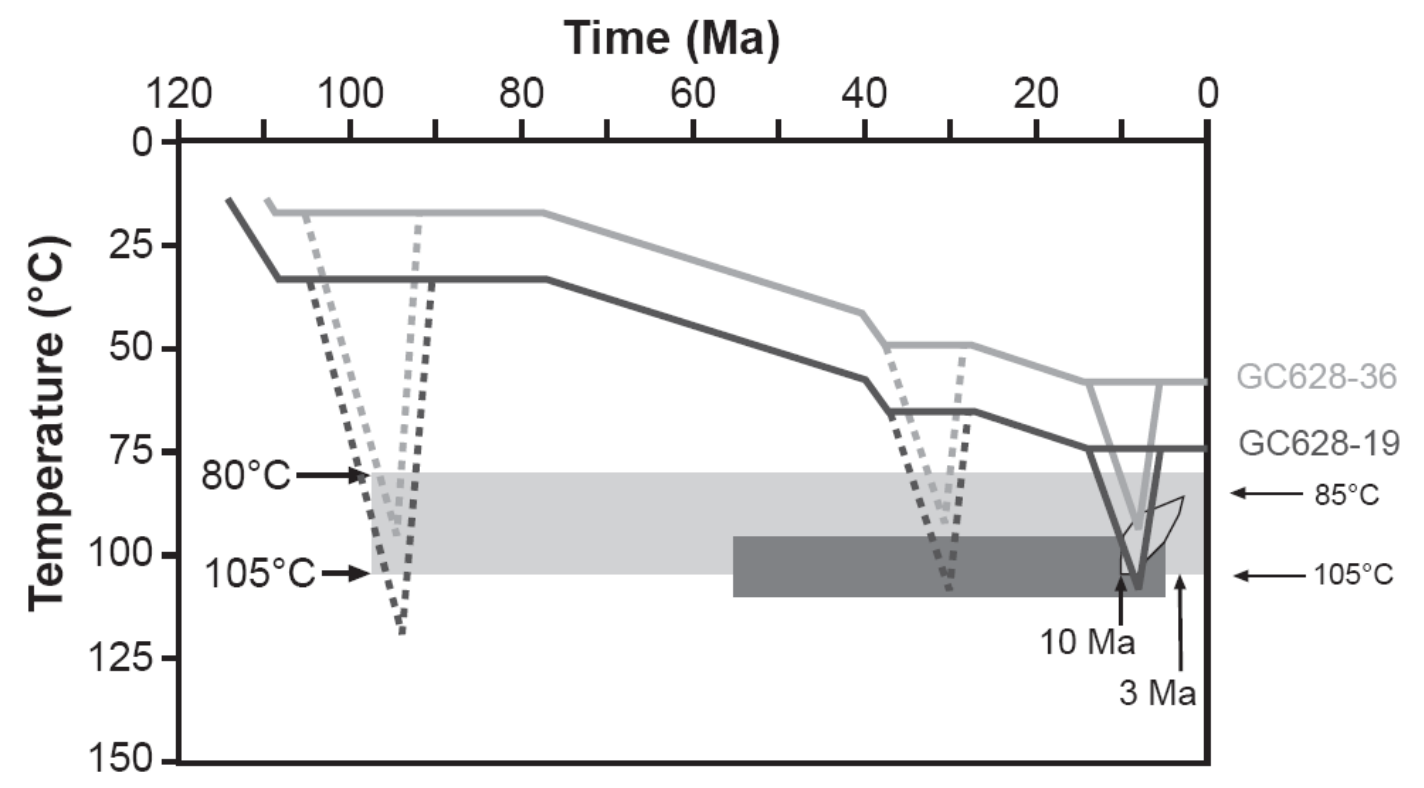




\section{Holford et al Figure 8}

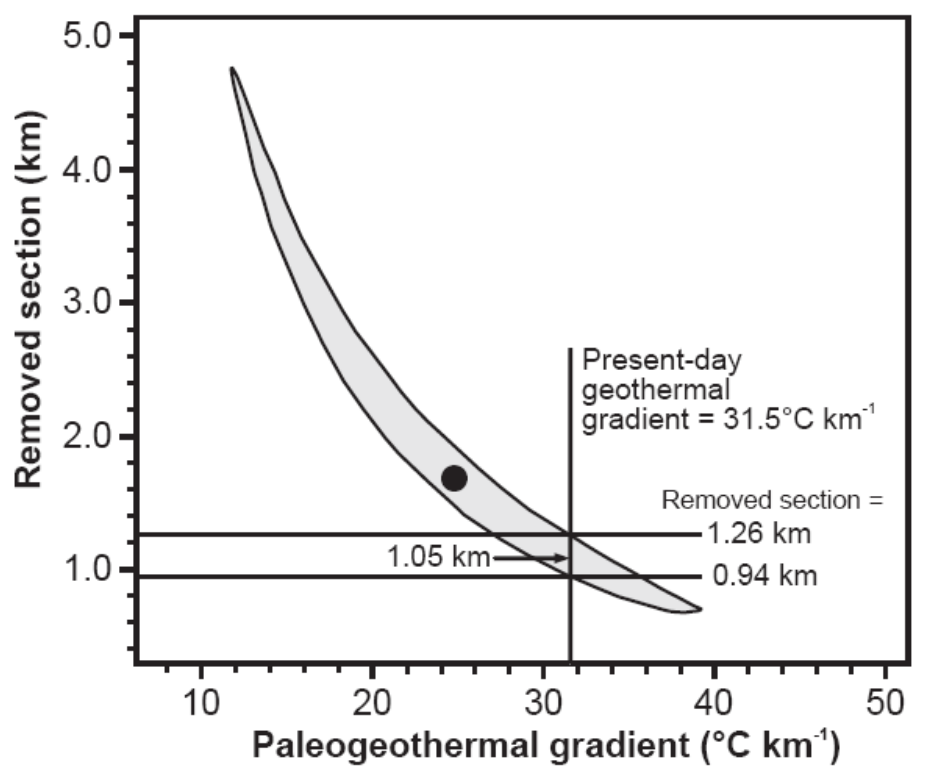




\section{Holford et al Figure 9}

(a)

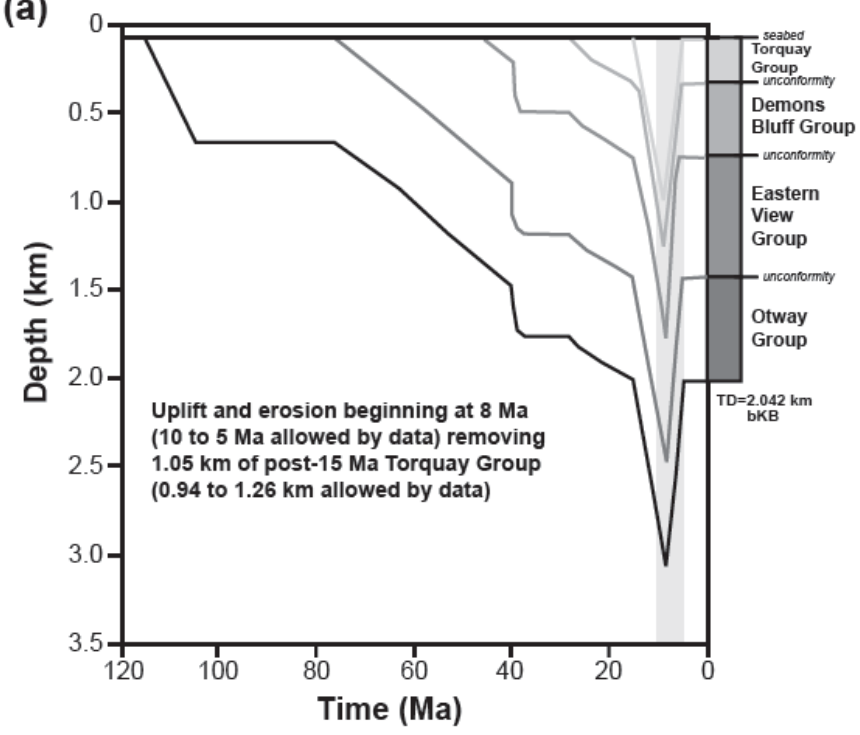

(b)

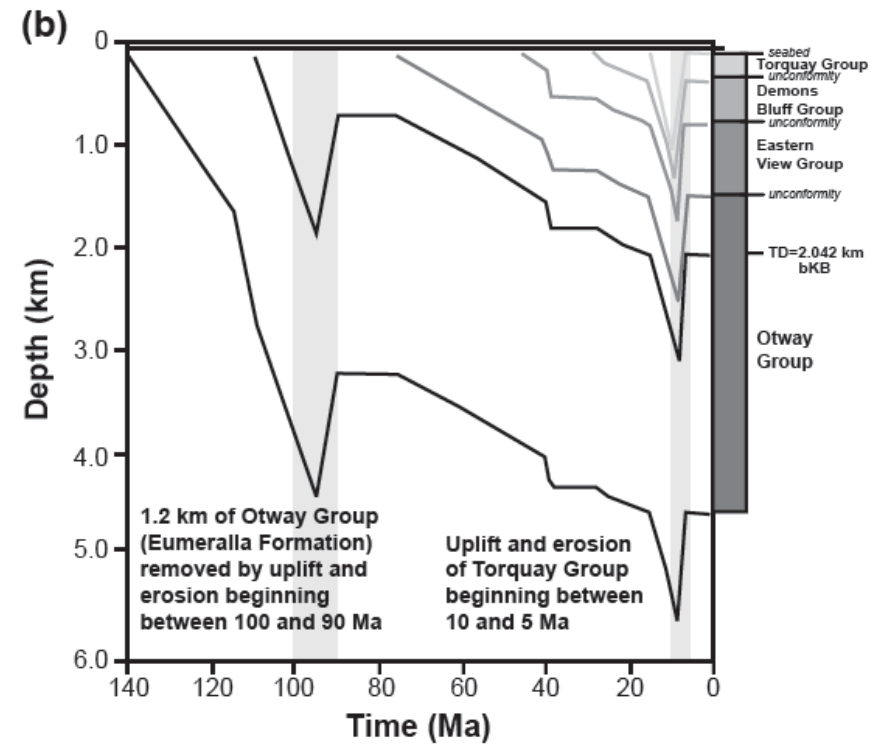




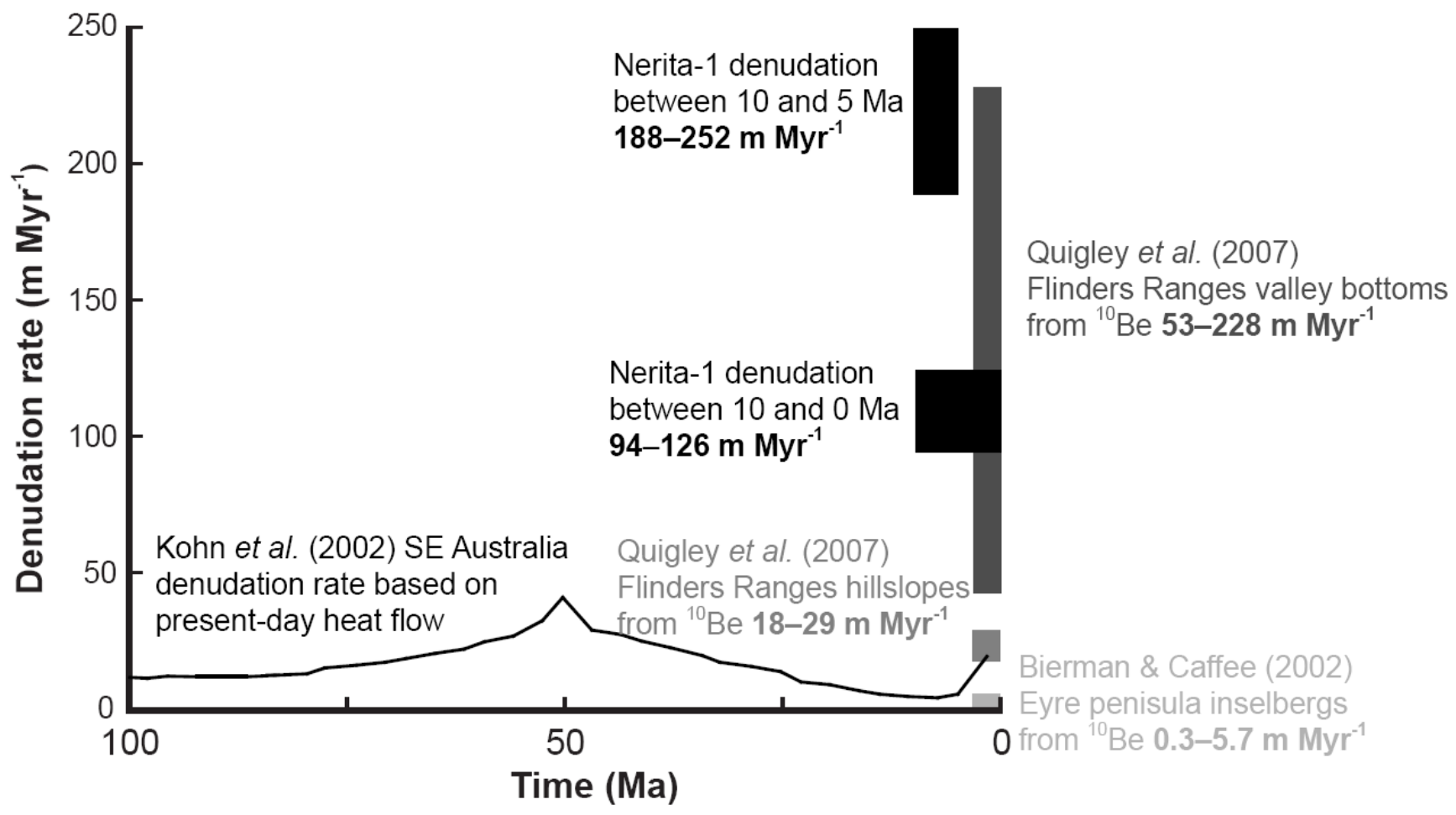




\section{Holford et al Figure 12}

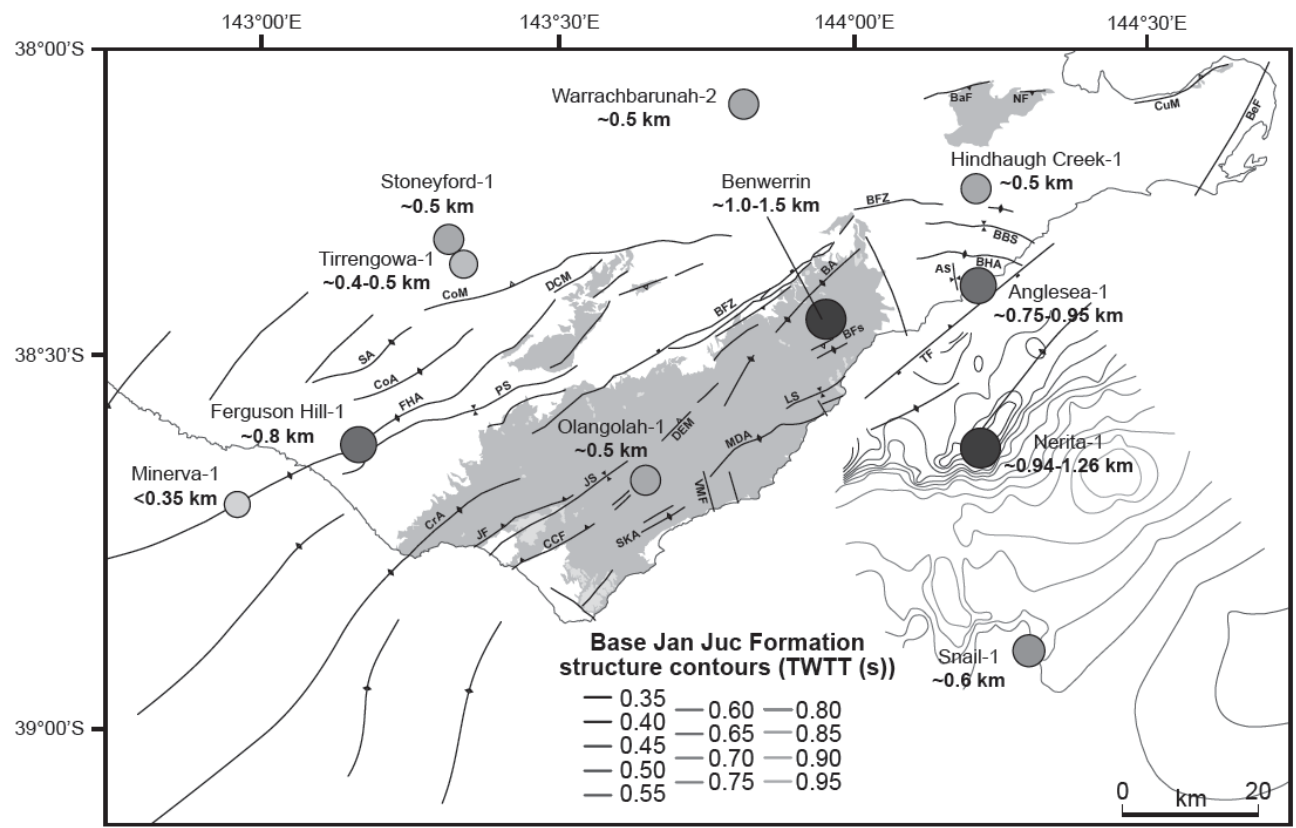

Late Miocene-early Pliocene exhumation estimates
$>1.0 \mathrm{~km}$
$>0.9 \mathrm{~km}$
$>0.5 \mathrm{~km}$
$>0.8 \mathrm{~km}$
$>0.4 \mathrm{~km}$
$>0.7 \mathrm{~km}$
$>0.3 \mathrm{~km}$
$>0.6 \mathrm{~km}$
$>0.2 \mathrm{~km}$
$>0.1 \mathrm{~km}$

Cenozoic structures

- Anticline - Normal fault

\% Syncline $\checkmark$ Monocline

r Reverse fault

AS Anglesea Siltstone DCM Deans Creek Monocline

BA Boonah Anticline DEM Devil's Elbow Monocline

BaF Barrabool Fault FHA Ferguson Hill Anticline

BBS Bells Beach Syncline JF Johanna Fault

BeF Bellarine Fault JS Johanna Syncline

BFs Benwerrin Folds

BFZ Bambra Fault Zone

BHA Bald Hills Anticline

CoA Coradjil Anticline

Ls Lorne Syncline

CoM Colac Monocline

PS Princetown Synclin

cra Crowes Anticline

SA Simpson Anticline

CrA Crowes Anticline

SkA Skenes Creek

VMF Torquay Fault $-0.50-0.75-0.95$ 
Holford et al Figure 13

(a)

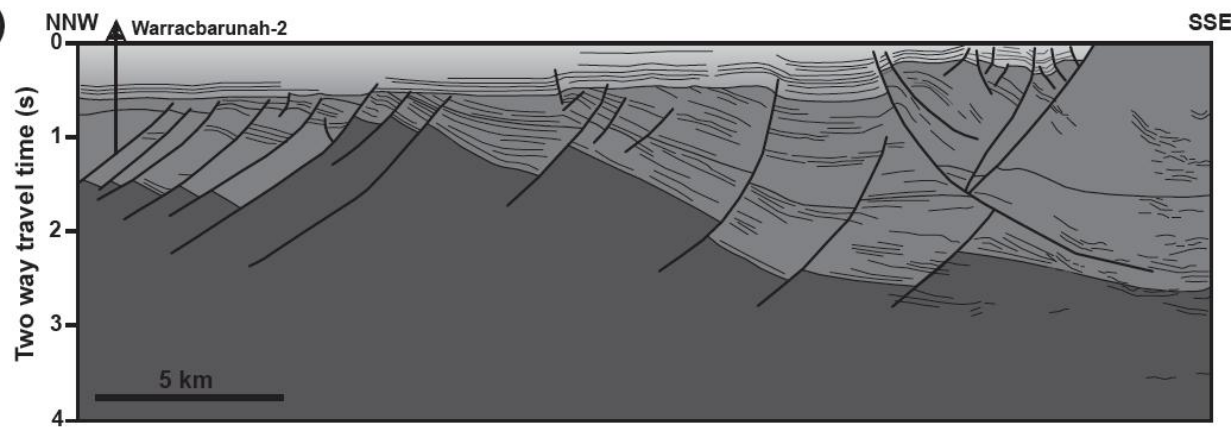

(b)

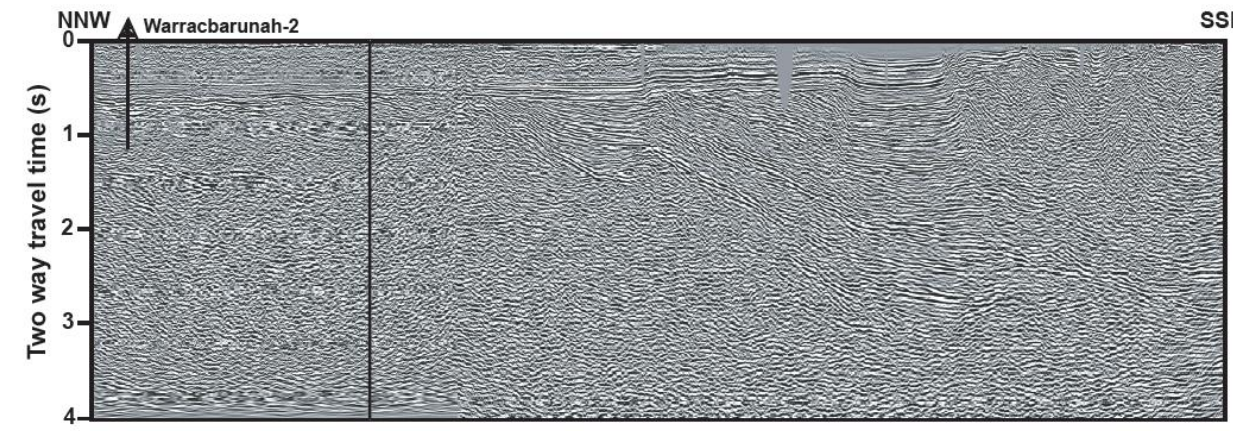

NNV

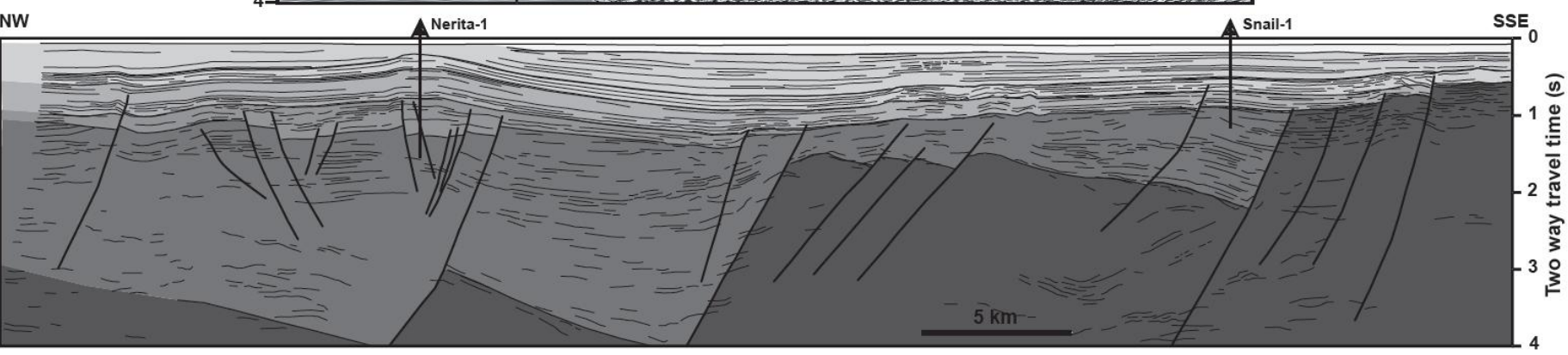

NNW

$A^{\text {Nerita-1 }}$

Snail-1

SSE 0

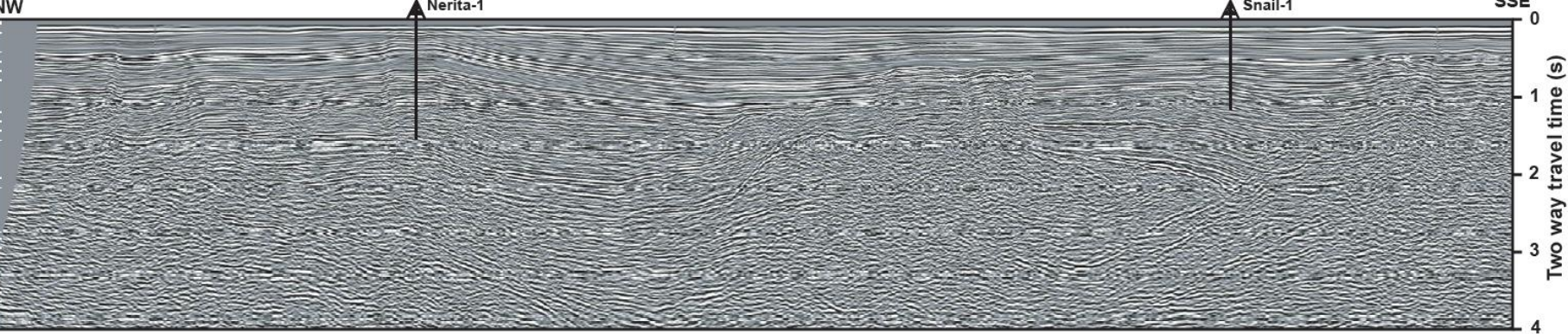

(c)

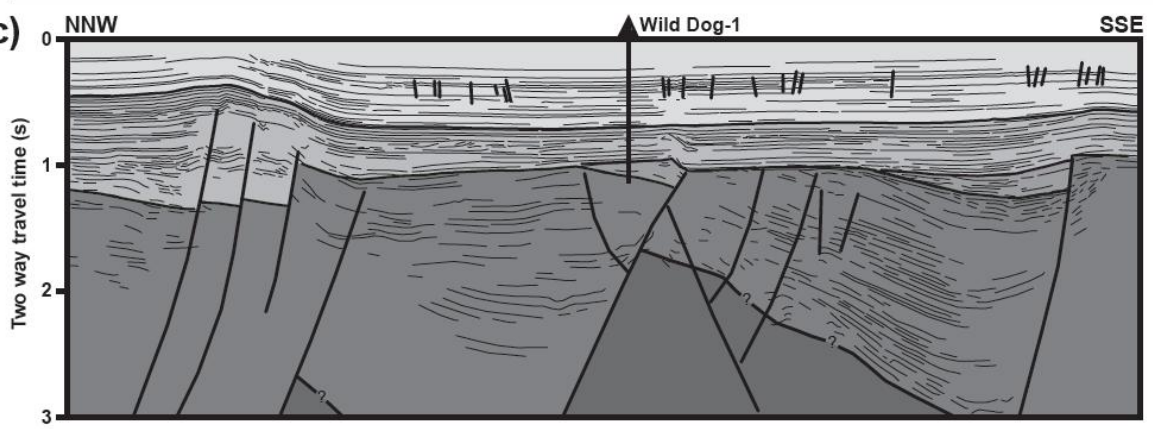

कू

Wild Dog-1

SSE

Brighton Group (Pliocene-Pleistocene) Torquay Group (Oliogocene-Miocene)

Demons Bluff Group (Eocene)

Eastern View Group (Campanian-Eocene)

Otway Group (Jurassic-Albian)

Basement (Silurian)

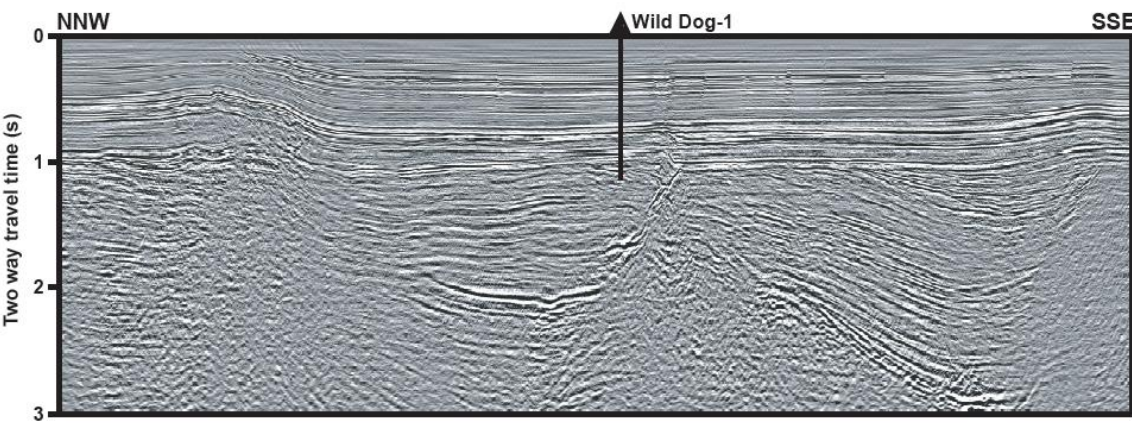




\section{Holford et al Figure 14}

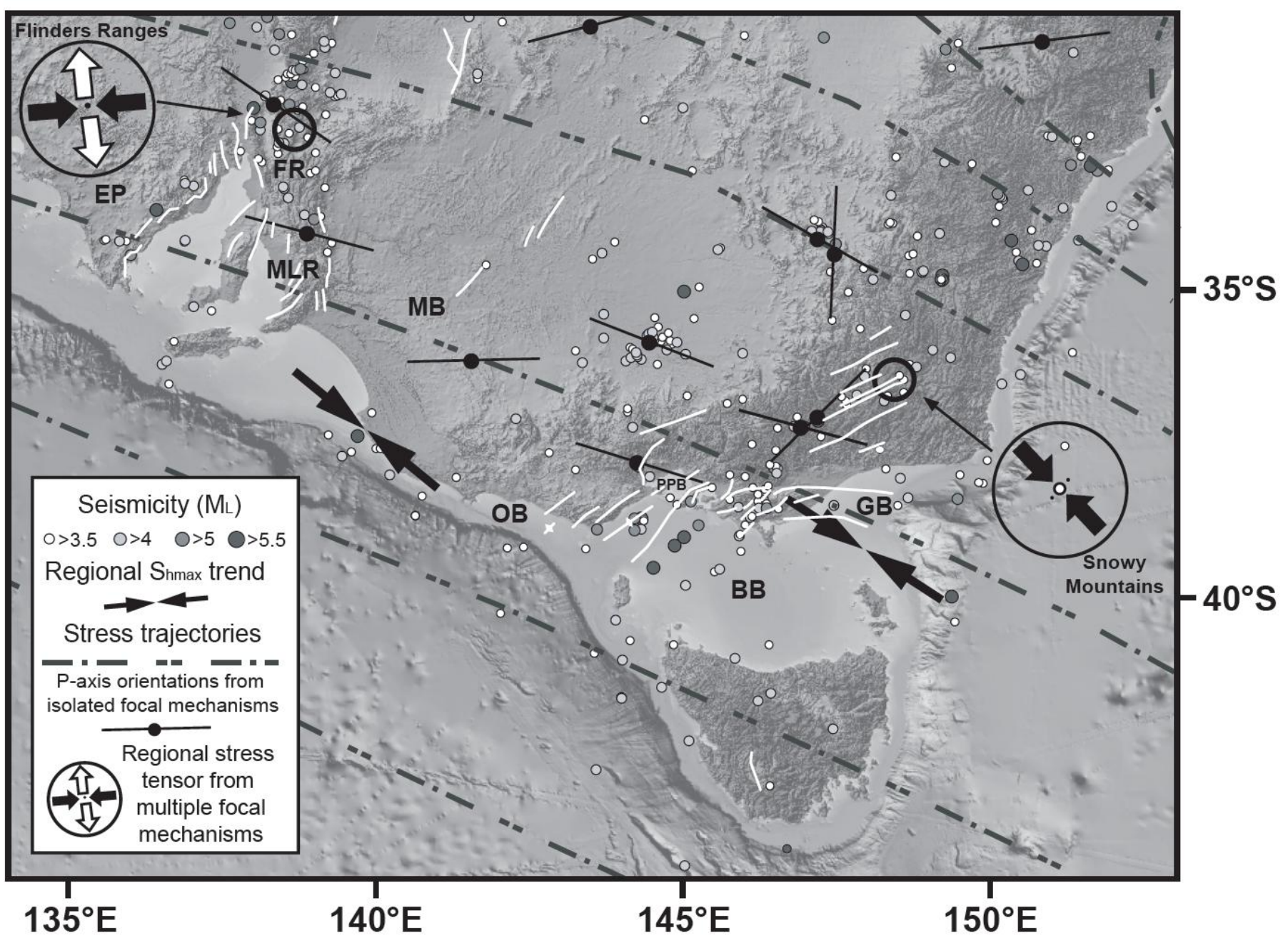

